\title{
Belediyelerde Nakit Akıș Tablosu Kullanımına Yönelik Bir Araştırma ve Nakit Akış Tablosu Analiz Teknikleri Üzerine Bir Uygulama
}

\section{A Research on the Use of Cash Flow Statements in Municipalities and an Application on Cash Flow Statement Analysis Techniques}

\author{
Ali Kablan ${ }^{1}$, Selçuk Altun² ${ }^{\circledR}$ \\ 'Dr. Öğr. Üyesi, Trakya Üniversitesi, Uzunköprü Uygulamalı Bilimler Yüksekokulu, Edirne, Türkiye \\ ${ }^{2}$ Beylikdüzü Belediyesi, Mali Hizmetler Müdürlüğü, İstanbul, Türkiye \\ ORCID: A.K. 0000-0003-2711-0034; S.A. 0000-0002-7793-2047
}

ÖZ

Son yıllarda yaşanan ekonomik istikrarsızlık, sektörlerdeki dalgalanmalar ve son yaşanan COVID-19 pandemisi ile birlikte, nakit kavramının bir işletme ya da faaliyette bulunan bir ekonomik birim için, kar kavramından daha önemli olduğu gerçeği bir kez daha gözler önüne serilmiştir. Özellikle kar amacı gütmeyen belediye birimlerinde, kardan daha önemli olan kamu ihtiyaçlarının karşılanabilmesi amacı, nakit kavramı üzerine odaklanılması gerekliliğini ifade etmektedir. Belediye birimleri ne kadar olumlu faaliyet sonucu elde ederse etsinler, bu sonuç nakit olarak desteklenmedikçe, uzun vadede kamusal mal ve hizmetlerin sürdürülebilirliği olumsuz etkilenecektir.

Bu amaçla çalışmada, Türkiye'de yer alan il ve büyükşehir belediyeleri ile nüfus yoğunluğu düşünüldüğünde, önemli bir yer tutan İstanbul ilçe belediyelerinin 2014-2018 yıllarına ilişkin, 445 adet faaliyet raporu içerik analizine tabi tutulmuştur. Belediyelerin faaliyet raporlarında nakit akış tablosuna yer verip vermediği ve bu tablolara ilişkin analiz tekniklerinin etkin bir şekilde kullanılıp kullanılmadığı hipotezleri araştırılmıştır. Ayrıca seçilmiş bir belediyenin verileri üzerinden gerçekleştirilen örnek bir uygulama ile belediyelerde nakit akış tablosunun hazırlanmasına ve nakit akış tablosu analizlerinin uygulanabilirliğine yer verilmiştir.

Anahtar kelimeler: Nakit akış tablosu, finansal tablo analizi, belediyelerde nakit yönetimi

\section{ABSTRACT}

As a result of economic instability, fluctuations in sectors and the recent COVID-19 pandemic, "cash" has been proven to be much more important than "profit" for any business. Cash is much more important in municipalities as they are non-profit organizations that aim to meet public needs. No matter how positive operating results they get, goods and services of municipalities will not be sustainable in the long term unless they are supported with cash.

For that purpose, 445 annual reports of province and metropolitan municipalities in Turkey between 2014 and 2018 were analyzed with content analysis. Whether cash flow statements were presented in annual reports and whether the analysis techniques for these statements were used effectively were investigated. In addition, a sample implementation of a cash flow statement preparation with cash flow analysis was provided using the data of a selected municipality, and the practicality of cash flow statements was discussed.

Keywords: Cash flow statement, financial statement analysis, cash management in municipalities

Başvuru/Submitted: 27.04.2020 Revizyon Talebi/Revision Requested: 05.06.2020 Son Revizyon/Last Revision Received: 09.06.2020 Kabul/Accepted: 12.06.2020 Sorumlu yazar/Corresponding author: Ali Kablan / alikablan@trakya.edu.tr 


\section{Extended Abstract}

The current study investigates whether cash flow statements, which are of utmost importance to economic sustainability, are used effectively by municipalities in Turkey. For that purpose, the questions of how often and how municipalities use and present cash flow statements are reviewed. In addition, a sample implementation of cash flow statement preparation with cash flow analysis is provided using the data of a selected municipality.

In the "Cash Flow Operating Activities Method" by Gup et al. (1993) the profile of a firm is analyzed based on its positive or negative net cash flow for business operations, investment operations and financing operations to make a decision about the cash flow structure of the firm. They state that cash flow profiles of a firm form eight models. Steyn-Bruwer and Hamman (2005) combined the modelling by Gup et al. (1993) with the organizational life cycle model by Mulford an Comiskey (1996) and related it to the models employed in the cash flow operating method.

There is a great body of research on the use of traditional ratio analysis for assessing the financial performance of incorporations in cash flow ratios literature. Gombola and Ketz (1983) used 40 ratios, including cash flow ratios and found cash flow form a factor separate and distinct from the factor of return ratios. As one of the earliest studies on the classification of cash flow ratios, Carslaw and Mills (1991) used 9 ratios and 4 categories. Similarly, Giacomino and Mielke (1993) categorized cash flow ratios using 9 ratios based on their sufficiency and efficiency. Mills and Yamamura (1998) employed cash flow ratios to test solvency and liquidity. Porwal and Jain'deki (2013) developed new ratios, including the company and investment operations ratio, to evaluate a company's economic performance. Zeller and Stanko (1994) and Kirkham (2012) focused on cash flow ratios that are used to evaluate liquidity only. Y1lmaz (1999) conducted the first study using cash flow ratios in Turkey. Gücenme and Arsoy (2006) concluded that employing basic cash flow ratios yields more information about a company's liquidity and solvency than the traditional ones. Güleç and Bektaş (2019) demonstrated the power of the statement of cash flows by using 8 fundamental cash flow ratios with 10 traditional ratios in the Manufacturing Industry from 7 different sub-sectors in Borsa Istanbul (BIST) between the periods of 2008 and 2017. Dereköy (2020) compared traditional and cash flow ratios to measure solvency and that accrual-based traditional ratios and cash-based cash flow ratios, give different results in the assessment of liquidity and solvency. Kepçe (2017) studied the association between the models of Gup and Samson and traditional ratios and concluded that although financial ratios were partially associated with the models, the correlation between them was weak. In other words, the models were not sufficient to characterize a company's financial standpoint. Although Beaver (1966) was the first to use cash flow to predict financial distress, Deakin (1972), Largay and Stickney (1980), Casey and Bartczak (1985), Gombola et al. (1987), and Rujoub et al. (1995) used cash flow ratios to predict bankruptcy and financial distress. Sayari and Mugan (2013) examined the effects of cash flow components on financial distress in Turkey. Çavuş and Başar (2020) investigated the relationship between cash flow ratios and financial success and failure that was identified with Z-Score and reported that cash flow ratios are effective in predicting financial distress. Lastly, Sakarya and Akkuş (2015) and Yılmaz and İçten (2018) employed cash flow based ratios for their multi-criteria decision making models.

Although there are many studies focusing on cash flow analyses in the Turkish private sector, there are no studies investigating the cash flow in local governing bodies. Therefore, the current study will make a significant contribution to the existing literature on the use of cash flow statements by municipalities and the implementation of cash flow analyses.

For the purpose of the study, 445 annual reports of provincial and metropolitan municipalities in Turkey between 2014 and 2018 were analyzed with content analysis. The annual reports of the municipalities were retrieved from the official websites of the municipalities.

A total of 445 annual reports of 51 provincial municipalities, 30 metropolitan municipalities and 39 district municipalities covering a 5-year period were reviewed by content analysis. Only 3 municipalities, Beyoğlu, Kağıthane and Sarıyer Municipalities, included cash flow statements in their annual reports. Therefore, the hypotheses, "Metropolitan municipalities include cash flow statements in their annual reports", "Provincial municipalities include cash flow statements in their 
annual reports" and "District municipalities include cash flow statements in their annual reports" were rejected. Content analysis revealed that most of the municipalities did not include cash flow statements in their annual reports. It suggests that cash flow statements are not used effectively and presented to the related bodies.

A guiding implementation of cash flow statement by the Beylikdüzü Municipality, which is quite important for municipalities was also presented. The cash flow statements for 2017, 2018 and 2019 were created and tested with cash flow analyses employed in the private sector. The analyses results showed that the Beylikdüzü Municipality fell in the Model 4 Growing Municipality. The ratio analysis also revealed that the Beylikdüzü Municipality concentrated on investment expenditures in 2018. Another municipality which was subjected to cash flow operations analysis was the Beyoğlu Municipality and it was in the Model 6 Young Municipality. 


\section{Giriş}

Özel sektörde faaliyet gösteren işletmeler gibi kamusal ihtiyaçları karşılama amacı güden belediye birimleri de, içinde bulunduğu dönemi olumlu faaliyet sonucu ile sonuçlandırsalar bile, nakit kaynakları açısından finansal sıkıntıya düşebilirler. Belediye birimleri ne kadar olumlu faaliyet sonucu elde ederse etsinler, bu sonuç nakit olarak desteklenmedikçe uzun vadede kamusal mal ve hizmetlerin sürdürülebilirliği olumsuz etkilenecektir. Belediye birimlerinin günlük giderlerini karşılayabilecek, cari yükümlülüklerini ödeyebilecek ve kamusal faaliyetlerini sürdürebilmek için gerekli varlıkları satın alabilecek kadar nakit varlığa sahip olmaları gerekmektedir. Kamusal ihtiyaçların karşılanması sırasında gerekli olan nakit miktarının sağlanamaması durumunda, belediyeler dış kaynaklardan yabancı kaynak temin etmek veya belediye varlıklarını satmak durumunda kalırlar. Bu durumda belediye birimleri sürdürülebilirliklerini sağlayamazlar. Bu nedenden dolayı belediye birimlerinin, geleceğe yönelik kamusal faaliyetlerini planlamaları ve doğru bir nakit politikası izlemeleri gerekmektedir.

Türkiye Muhasebe Standardı (TMS) 1 Finansal Tabloların Sunuluşu’nda belirtildiği üzere (md. 27); İşletmeler, nakit akış1 bilgileri hariç, finansal tablolarını tahakkuk esasına göre düzenlerler. Tahakkuk esası; muhasebeye konu işlem ve olayların kaydedilmesinde, nakden tahsil edilip edilmemesine bakılmaksızın olayın gerçekleştiği veya ortaya çıktığı anda muhasebeleştirilmesi anlamına gelmektedir (Orhan \& Serçemeli, 2013, s. 323; Weygandt, Kimmel \& Kieso, 2009, s. 101). Nakit esası ise, gelir ve giderlerin fiilen tahsil edildiğinde ya da ödendiğinde kayıt altına alındığı bir sistemdir (Pinson, 2007, s. 9). Türkiye'de 2006 yılından itibaren 5018 sayılı Kamu Mali ve Kontrol Kanunu ile birlikte, kamu reformu çalışmaları kapsamında devlet muhasebe uygulamaları nakit esaslı muhasebe sisteminden, tahakkuk esaslı muhasebe sistemine geçmiştir.

Nakit akış tablosu ise, tahakkuk esasına göre hazırlanmayan tek finansal tablo niteliğinde olup, nakit esasına göre hazırlanmaktadır. Bu sayede nakış akış tablosu, tahakkuk esasına göre hazırlanmış olan mali tablo bilgilerinin nakit esasına göre finansal tablo okuyucularına sunulması için kullanılmaktadır (Örten, Kaval \& Karapınar, 2015). Daha kapsamlı bir ifade ile nakit akıs tablosu, diğer kapsamlı gelir tablosunda bulunan dönem kârının, finansal durum (bilanço) tablosunda bulunan nakit ve nakit benzerlerine hangi nedenlerle eşit olmadığını açıklamak için kullanılmakta ve temel finansal tablolar arasında yer almaktadır (Özerhan \& Yanık, 2010). Nakit akış tablosu, işletmedeki para akışını özetleyerek hem geçmişin finansman politikasının değerlendirilmesinde hem de geleceğe yönelik nakit planlamasının yapılmasında yönetime ve ilgili taraflara önemli bilgiler sunmaktadır (Sarığlu \& Demir, 2008).

Bu amaçla çalışmada; sürdürülebilirlik için büyük önem arz eden nakit akış tablosunun, "Türkiye'de belediye birimleri tarafından etkin kullanılmaktadır" ifadesinin doğruluğu araştırılacaktır. Araştırma sorusunun geçerliliği, Türkiye'de yer alan il ve büyükşehir belediyeleri ile nüfus yoğunluğu düşünüldüğünde, önemli bir yer tutan İstanbul ilçe belediyelerinin 2014-2018 dönemlerine ilişkin faaliyet raporları içerik analizine tabi tutularak incelenecektir. Ayrıca seçilmiş bir belediyenin verileri üzerinden gerçekleştirilen örnek bir uygulama ile belediyelerde nakit akış tablosunun hazırlanmasına ve nakit akış tablosu analizlerinin uygulanabilirliğine yer verilecektir.

\section{Nakit Akış Tablosu}

Muhasebe standartları açısından ele alındığında nakit akış tablosu; TMS 1 Finansal Tabloların Sunuluşu, Büyük ve Orta Boy İşletmeler için Finansal Raporlama Standardı (BOBİ FRS) Bölüm 1 Kavramsal Çerçeve ve Finansal Tablolar ile Devlet Muhasebe Standardı (DMS) 1 Mali Tabloların Sunuluşu standartlarında, bir şirketin veya kamu kuruluşunun hazırlaması gereken dört temel finansal tablodan biri olarak karşımıza çıkmaktadır. Ayrıca kamu idarelerinin muhasebe sistemini düzenleyen, Merkezi Yönetim Muhasebe Yönetmeliği (MYMY) md 514’te, Genel Yönetim Muhasebe Yönetmeliği (GYMY) md 313’te ve Mahalli İdareler Bütçe ve Muhasebe Yönetmeliği md 485’te; kamu kurum ve kuruluşları tarafından düzenlenmesi gereken temel mali tablolar arasında gösterilmektedir.

Nakit Akış Tablosu, “Finansal Durumdaki Değişiklikler Tablosu” adı ile ilk kez 1971 yılında Amerikan Muhasebe İlkeleri Kurulu tarafından zorunlu hale getirilmiştir. Daha sonra nakit akış tablosu adını alan bu tablo, gelir tablosunun tamamlayıcısı 
olarak düzenlenmeye başlanmıştır (Fridson \& Alvarez, 2002, s. 91). Nakit akış tablosu, ekonomik bir birimin nakit yaratma kabiliyeti ve bu fonların kullanımını değerlendirmek için son derece faydalı bilgiler sunmakla (Rezaei \& Jafaar, 2015) birlikte, birbirini izleyen iki dönem arasındaki nakit ve nakde eşdeğer varlık tutarlarındaki değişmeyi açıklamayı amaçlamaktadır (Akdoğan \& Tenker, 2010, s. 358). Nakit akış tablosu, yatırımcılara, kredi verenlere ve diğer ilgililere aşağıdaki hususları değerlendirmek için bilgi sağlamaktadır (Kepçe, 2017, s. 38-39):

- İşletmenin gelecekteki nakit akışlarını oluşturma yeteneğinin,

- İşletmenin yükümlülüklerini yerine getirme becerisinin,

- Kâr veya zarar ile işletme faaliyetlerinden net nakit akışı arasındaki farkın nedenlerinin,

- Dönem içinde gerçekleşen yatırım ve finansman faaliyetlerine ilişkin nakit akışlarının değerlendirilmesi.

Önemi itibariyle bir çok muhasebe yönetmeliği ve standardına konu olan nakit akış tablosu;

- Genel Yönetim Muhasebe Yönetmeliği,

- Merkezi Yönetim Muhasebe Yönetmeliği,

- TMS 1 Finansal Tabloların Sunuluşu Standard,

- DMS 1 Mali Tabloların Sunuluşu Standardı,

- BOBİ FRS Bölüm 1 Kavramsal Çerçeve ve Finansal Tablolar,

- TMS 7 Nakit Akış Tabloları Standardı,

- DMS 2 Nakit Akış Tabloları Standardı,

- BOBİ FRS Bölüm 2 Nakit Akış Tablosu

yönetmelik ve standartlarının hepsinde kendisinden söz ettirmekle birlikte, adına standart düzenlenen tek mali tablo olarak karşımıza çıkmaktadır.

TMS 7 Nakit Akış Tablosu ismini taşıyan standardın amacı, işletmenin nakit ve nakit benzeri değerlerindeki değişiklikler hakkında, döneme ilişkin nakit akışlarını işletme, yatırım ve finansman faaliyetlerine göre sınıflandırarak sunumunun yapılmasıdır. ABD Finansal Raporlama Standartları Kurulu'na (FASB) göre nakit akış tablosunun temel amacı ise; bir şirketin likiditesini, ödeme gücünü ve finansal uyumunu değerlendirmektir (Jooste, 2006).

Çalışmanın konusunu oluşturan belediye birimlerinde nakit akış tablosu, belirli bir raporlama dönemi itibariyla belediyeye ait nakit ve nakit benzeri varlıklarının akışını gösteren bir mali tablo olmakla birlikte; DMS 2'ye göre; “Nakit akış tablosu, raporlama döneminde nakit giriş kaynaklarl ve nakit harcanan kalemler ile raporlama tarihindeki nakit tutarını gösterir. Nakit akış bilgileri, bir kamu idaresinin faaliyetlerinin finansmanı için gerekli olan nakdi nasıl karşıladığını ve bu nakdi ne şekilde kullandığının anlaşılmasını sağlar" şeklinde ifade edilmektedir. GYMY md 316'da ise; "Nakit akış tablosu genel yönetimin ve kapsama dâhil her bir kamu idaresinin dönem nakit tahsilatlarl ve ödemeleri, mali ve mali olmayan varlıkları ile yükümlülüklerine ilişkin işlemlerden kaynaklanan nakit akışlarını gösterir" şeklinde tanımlanmaktadır.

Gerek DMS 2'de, gerekse de GYMY md 316/6'da nakit akış tablosu, döneme ilişkin nakit akışlarının esas faaliyetlerden, yatırım faaliyetlerinden ve finansman faaliyetlerinden kaynaklanan nakit akışları şeklinde sınıflandırılarak sunulduğu bir tablo olarak ifade edilmektedir. DMS 2 Nakit Akış Tablosu Standardında bu faaliyetler aşağıdaki şekilde ifade edilmektedir. 
- Esas Faaliyetler: Bir kamu idaresinin yatırım ve finansman faaliyetleri dışındaki faaliyetleridir. Esas faaliyetlere ilişkin net nakit akışlarının tutarı kamu idaresinin faaliyetini yürütebilme, yükümlülüklerini ödeyebilme ve dış finansman kaynaklarına başvurmaksızın yeni yatırımlar yapabilme kapasitesini yansıtır. Esas faaliyetlerden kaynaklanan nakit akışları, esasen kamu idaresinin temel nakit getiren faaliyetlerinden elde edilir.

- Finansman Faaliyetleri: Kamu idaresinin net değer ve borçlarının büyüklüğünde ve niteliğinde değişikliklere neden olan faaliyetlerdir.

- Yatırım Faaliyetleri: Uzun vadeli varlıkların elde edilmesi ve elden çıkarılmasına ilişkin faaliyetlerdir.

GYMY Ekler/Örnek-6'da da gösterilmekle birlikte, DMS 2 Nakit Akış Tablosu Standardında yer alan nakit akış tablosu sunumu Tablo 1'de gösterilmektedir. Aynı zamanda Tablo 1'de, GYMY'nde yer alan (md. 46/6) tüm kamu kurum ve kuruluşlarının tabi olduğu hesap planında yer alan hesaplar ile, DMS 2 Nakit Akış Tablosu Standardında yer alması gereken nakit akış bölümlerine ilişkin eşleştirme yapılmıştır. Kamu kurum ve kuruluşları tarafından, DMS 2'ye göre Nakit Akış tablosu hazırlanırken, ilgili döneme ait hesap hareketleri ve nakit akış tablosunda ait olduğu bölüme ilişkin eşleştirme Tablo l'de gösterildiği şekilde yapacaktır.

Tablo 1: DMS 2 Nakit Akış Tablosu Standardında Yer Alan Kamu İdaresi Nakit Akış Tablosu Sunumu

\begin{tabular}{|c|c|c|c|}
\hline \multicolumn{4}{|c|}{ 1. BÖLÜM FAALIYETLERDEN KAYNAKLANAN NAKİT AKIȘLARI (DMS 2) } \\
\hline & & GYMY Hesap Planı & Nakit Akış Tablosu \\
\hline & & A-) Faaliyetlerden Sağlanan Nakit Girișleri & A-) Faaliyetlerden Sağlanan Nakit Girișleri \\
\hline 600 & 1 & Vergi Gelirleri & Vergi Gelirleri \\
\hline 600 & 3 & Teșebbüs ve Mülkiyet Gelirleri & Teșebbüs ve Mülkiyet Gelirleri \\
\hline 600 & 4 & Alınan Bağıș ve Yardımlar & Alınan Bağıș ve Yardımlar \\
\hline 600 & 5 & Faizler, Cezalar, Paylar & Faizler, Cezalar, Paylar \\
\hline \multirow[t]{2}{*}{600} & 6 & Sermaye Gelirleri & Menkul Kıymet ve Varlık Gelirleri \\
\hline & & $\begin{array}{l}\text { B-) Faaliyetlerden Kaynaklanan Nakit } \\
\text { Çıkıșları }\end{array}$ & $\begin{array}{l}\text { B-) Faaliyetlerden Kaynaklanan Nakit } \\
\text { Çıkışları }\end{array}$ \\
\hline 630 & 1 & Personel Giderleri & Personel Giderleri \\
\hline 630 & 2 & $\begin{array}{l}\text { Sosyal Güvenlik Kurumlarına Devlet } \\
\text { Primleri }\end{array}$ & $\begin{array}{l}\text { Sosyal Güvenlik Kurumlarına Devlet } \\
\text { Primleri }\end{array}$ \\
\hline 630 & 3 & Mal ve Hizmet Giderleri & Mal ve Hizmet Giderleri \\
\hline 630 & 4 & Faiz Giderleri & Faiz Giderleri \\
\hline 630 & 5 & Cari Transferler & Cari Transferler \\
\hline 630 & 7 & Sermaye Transferleri & Sermaye Transferleri \\
\hline 630 & 8 & Borç verme & Borç verme \\
\hline 630 & 30 & Proje Kapsamında Yapılan Cari Giderler & Proje Kapsamında Yapılan Cari Giderler \\
\hline \multirow[t]{2}{*}{630} & 99 & Diğer Giderler & Diğer Giderler \\
\hline & & $\begin{array}{l}\text { C-) Faaliyetlerden Sağlanan Net Nakit } \\
\text { Akışı (A-B) }\end{array}$ & $\begin{array}{l}\text { C-) Faaliyetlerden Sağlanan Net Nakit Akışı } \\
\text { (A-B) }\end{array}$ \\
\hline
\end{tabular}




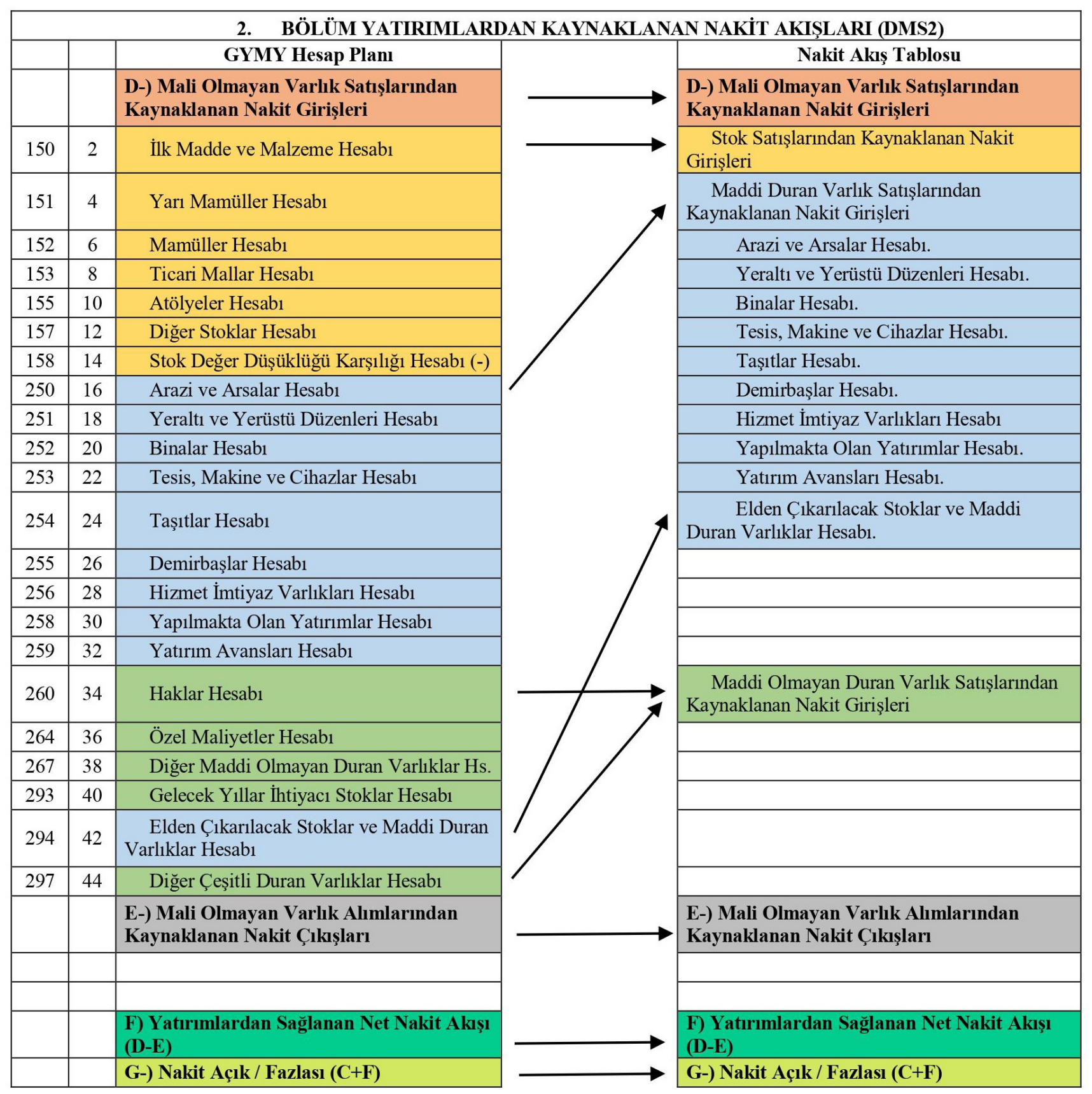




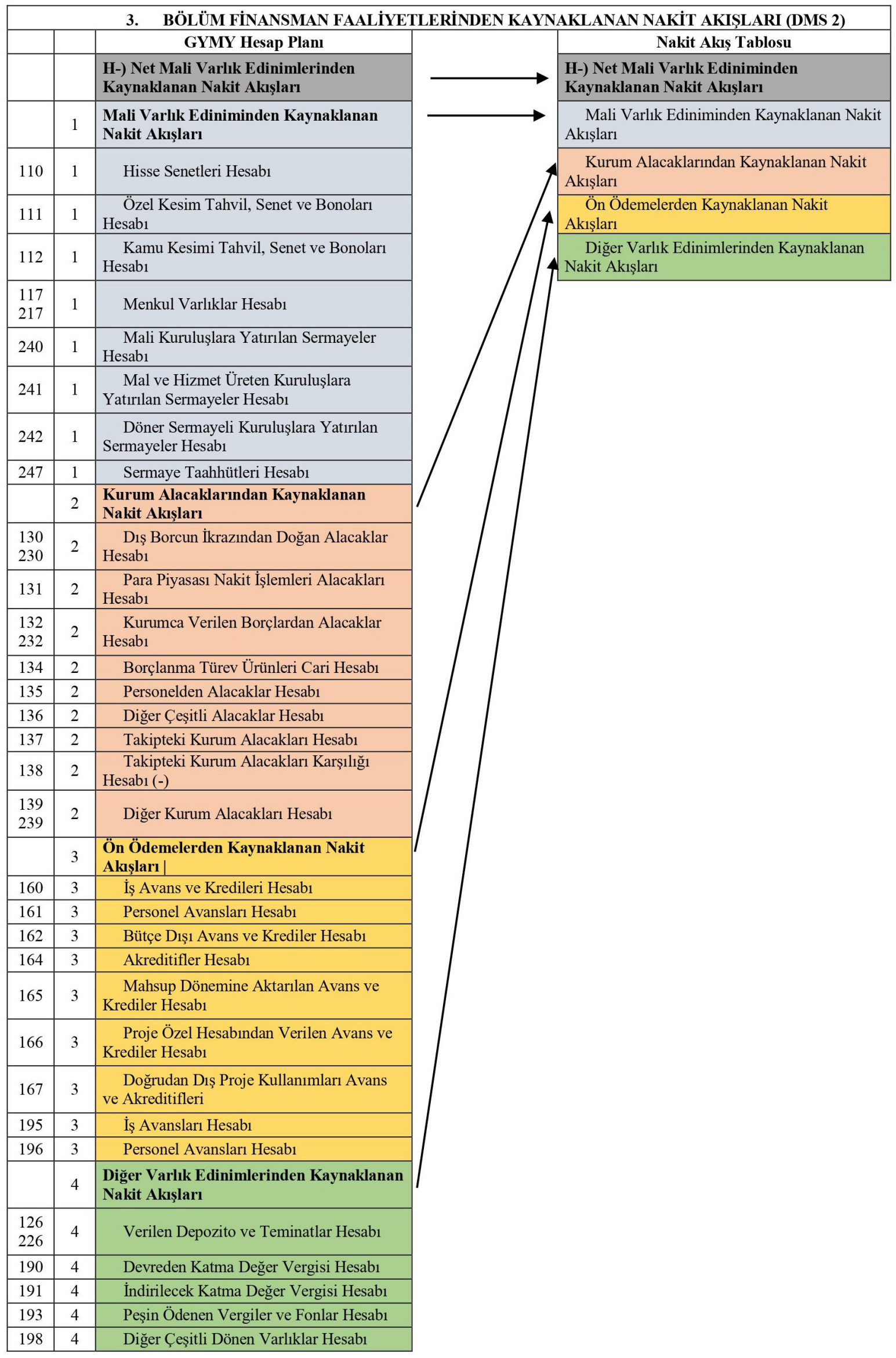




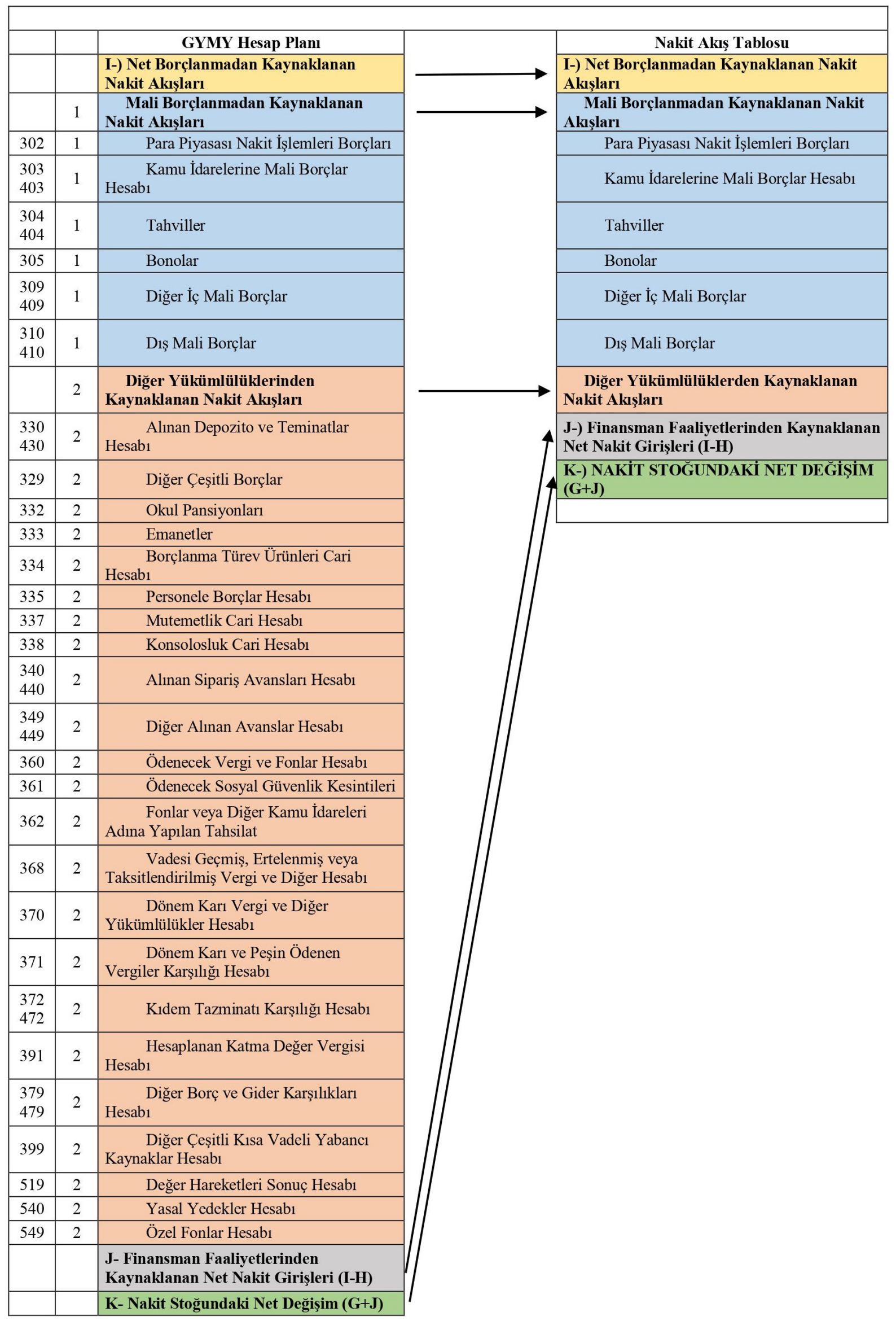




\begin{tabular}{|c|c|c|c|}
\hline \multicolumn{4}{|c|}{ HAZIR DEĞERLER NAKİT DEĞIȘíMI } \\
\hline & & GYMY Hesap Planı & Nakit Akış Tablosu \\
\hline & & İSTATİSTIKKSL HATA (K-L) & İTATISTIKSEL HATA (K-L) \\
\hline & & $\begin{array}{l}\text { L) HAZIR DEĞERLER NAKITT } \\
\text { DEĞİȘIMI }\end{array}$ & L-) HAZIR DEĞERLER NAKİT DEĞIşiMI \\
\hline 100 & 1 & Kasa Hesab1 & Kasa Hesab1 \\
\hline 101 & 2 & Alınan Çekler Hesabı & Alınan Çekler Hesabı \\
\hline 102 & 3 & Banka Hesab1 & Banka Hesabı \\
\hline 103 & 4 & $\begin{array}{l}\text { Verilen Çekler ve Gönderme Emirleri } \\
\text { Hesabı }\end{array}$ & Verilen Çekler ve Gönderme Emirleri Hesabı \\
\hline 104 & 5 & Proje Özel Hesabı & Proje Özel Hesabı \\
\hline 105 & 6 & Döviz Hesabı & Döviz Hesabı \\
\hline 106 & 7 & Döviz Gönderme Emirleri Hesabı & Döviz Gönderme Emirleri Hesabı \\
\hline 107 & 8 & $\begin{array}{l}\text { Elçilik ve Konsolosluklar Nezdindeki } \\
\text { Paralar Hesabı }\end{array}$ & $\begin{array}{l}\text { Elçilik ve Konsolosluklar Nezdindeki Paralar } \\
\text { Hesabi }\end{array}$ \\
\hline 108 & 9 & Diğer Hazır Değerler Hesabı & Diğer Hazır Değerler Hesabı \\
\hline 109 & 10 & $\begin{array}{l}\text { Banka Kredi Kartlarından Alacaklar } \\
\text { Hesabı }\end{array}$ & Banka Kredi Kartlarından Alacaklar Hesabı \\
\hline
\end{tabular}

Kaynak: GYMY'nde yer alan kamu kurum ve kuruluşlarının tabi olduğu hesap planında yer verilen hesaplar ile,

DMS 2 Standardında yer alan nakit akış tablosu dikkate alınarak ilgili yazarlar tarafından oluşturulmuştur.

\section{Nakit Akış Tablosu Analiz Teknikleri}

Nakit akış tablosu analiz teknikleri ile ilgili litaretür incelendiğinde; çalışmaların, "Nakit Akışlarının Sağlandığg Faaliyetler Yöntemi” ile "Nakit Akış Oranlarının İncelenmesi” üzerinde yoğunlaştı̆̆ı görülmektedir. Bu sebeple çalışmada, bu iki teknik kullanılarak uygulama ele alınacaktır.

\subsection{Nakit Akış Tablosu’nun Nakit Akışlarının Sağlandığı Faaliyetler Yöntemi İle Analizi}

Gup, Samson, Dugan Kim ve Jittrapanun (1993, s. 73-79) çalışmasında ortaya koydukları, "Nakit Akışlarının Sağlandı̆̆ Faaliyetler Yöntemi"nde, işletmenin nakit akış tablosunun üç ana bölümü olan işletme faaliyetleri, yatırım faaliyetleri ve finansman faaliyetlerine ilişkin net nakit akışının pozitif veya negatif olmasına göre profili incelenerek, nakit yapısı ve işletme hakkında değerlendirmeler yapılmaktadır. Gup ve ark. (1993) çalışmasında, işletmenin nakit akış profillerinin sekiz model oluşturduğunu belirtmektedir. Bu sekiz model, işletmenin nakit akış tablosunun üç temel bölümünün işaretine göre (pozitif ya da negatif) siralanmaktadır.

Nakit akışlarının sağlandığı faaliyetler modeli, aşağıda Tablo 2'de sunulduğu gibi, faaliyetlerin sağladığı nakit akışlarının büyüklüklerini dikkate almadan, pozitif (+) ve negatif (-) olarak sekiz model halinde değerlendirmektedir.

\begin{tabular}{|c|c|c|c|c|}
\hline Modeller & İşletme Profilleri & $\begin{array}{c}\text { İşletme } \\
\text { Faaliyetlerinden } \\
\text { Nakit Akışı } \\
\end{array}$ & $\begin{array}{c}\text { Yatırım } \\
\text { Faaliyetlerinden } \\
\text { Nakit Akışı } \\
\end{array}$ & $\begin{array}{c}\text { Finansman } \\
\text { Faaliyetlerinden } \\
\text { Nakit Akışı } \\
\end{array}$ \\
\hline Model 1 & Nadir Durum & + & + & + \\
\hline Model 2 & Başarılı İşletme & + & - & - \\
\hline Model 3 & Gerileyen veya Yeniden Yapılanan İşletme & + & + & - \\
\hline Model 4 & Büyüyen İşletme & + & - & + \\
\hline Model 5 & Küçülen İşletme & - & + & + \\
\hline Model 6 & Genç İşletme & - & - & + \\
\hline Model 7 & Likiditasyona Giden İşletme & - & + & - \\
\hline Model 8 & Nadir Durum & - & - & - \\
\hline
\end{tabular}

Steyn-Bruwer ve Hamman (2005), Gup ve ark. (1993)'nin yaptıkları modellemeyi, Mulford ve Comiskey (1996)'nin yaptı̆̆ “İşletme Yaşam Döngüsü” ile birleştirerek, işletme yaşam döngüsünü nakit akışlarının sağlandığı faaliyetler yönteminde 
yer alan modellerle ilişkilendirmişlerdir (Kargın \& Aktaş, 2011, s. 11). Nakit akışlarının sağlandığı faaliyetler yöntemine göre belirlenen modellerin Steyn, Bruwer ve Hamman (2005) tarafından işletme yaşam döngüsüne uyarlanmış hali özetle Tablo 3'de yer almaktadir.

Tablo 3: Nakit Akış Profilleri ve İşletme Yaşam Döngüsü

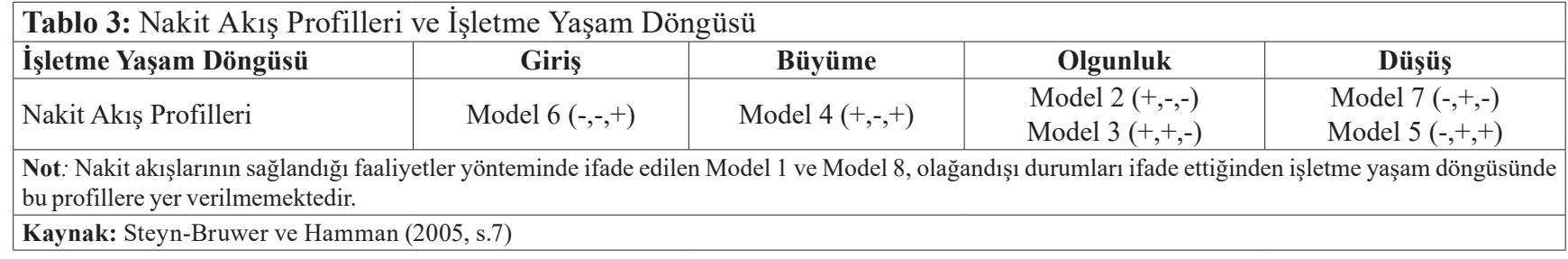

\subsection{Nakit Akış Tablosu'nun Oran Analizi Yöntemi İle Analizi}

Nakit akış tablosu, finansal tablo setinin bir parçası olmasına rağmen, finansal tablo analizi söz konusu olduğunda bilanço veya gelir tablosu kadar dikkate alınmamaktadır. Nakit akışlarının temel olarak muhasebe eğitimi içerisinde yeterince ilgi görmemesinin nedeni, muhasebe, finans ve denetim ders kitaplarının çoğunun sadece geleneksel oranları içermesi ve eğitimcilerin finansal tablo analizinde sadece geleneksel oranları vurgulamasıdır (Yamamura \& Mills, 1998). Ancak nakit akış oranları analizinin, geleneksel bilanço ve gelir tablosu oranlarıla birlikte kullanılması, ekonomik birimlerin finansal açıdan güçlü ve zayıf yönlerinin daha iyi anlaşılması sağlanmaktadır (Carslaw \& Mills, 1991).

Literatüre bakıldığında; ekonomik birimlerin finansal performansını değerlendirmede geleneksel oran analizi kadar nakit akışlarını kullanan çalışmalar yaygın olmamakla birlikte; Gombola ve Ketz (1983), yaptıkları çalışmada, nakit akışına dayalı oranlar da dahil olmak üzere 40 oran kullanmış ve nakit akış oranlarının, karlılık oranlarından farklı bilgilere sahip olabileceğini ve göz ardı edilmemesi gerektiğini öne sürmüştür. Carslaw ve Mills (1991), nakit akış oranlarını sistematik olarak sınıflandıran ilk çalışmalardan biri olup, nakit akış oranlarını 9 oran kullanarak 4 kategoriye ayırmaktadır. Giacomino ve Mielke (1993), nakit akış oranlarını 9 oran kullanarak yeterlilik ve verimlilik kategorilerine ayırmaktadır. Mills ve Yamamura (1998), ödeme gücü ve likiditeyi test etmek için nakit akış oranları ve bir şirketin uygulanabilirliğini ölçen kategoriler olarak sınıflandırmıştır. Porwal ve Jain'deki (2013), işletme ve yatırım faaliyetleri oranı gibi şirketlerin ekonomik durumunu yansıtmak için diğer çalışmalardan farklı yeni oranlar geliştirmişlerdir. Zeller ve Stanko (1994) ve Kirkham (2012), sadece likiditeyi ölçen nakit akış oranları üzerinde odaklanmaktadır. Yılmaz (1999), Türkiye'de nakit akış oranlarını ilk kez kullanan çalışma olarak karşımıza çıkmaktadır. Gücenme ve Arsoy (2006), temel nakit akış oranlarının kullanılması sonucu geleneksel oranlara nazaran şirketin likiditesi ve ödeme gücü hakkında daha fazla bilgi edinildiğini belirtmiş̧ir. Güleç ve Bektaş (2019), çalışmasında 10 geleneksel oranla, 8 temel nakit akış oranını kullanarak 2008-2017 yılları arasında BIST’te yer alan 7 farklı alt sektörden İmalat Sanayiinde uygulamaya yer vermiş nakit akış tablosunun gücünü ortaya koymuştur. Dereköy (2020), borç ödeme gücünün ölçülmesinde geleneksel oranlar ile nakit akış oranlarını karşılaştırmış ve borç ödeme gücünün değerlendirilmesinde, geleneksel oranlar ile nakit akış oranlarının farklı sonuçlar verdiğini ortaya koymuştur. Kepçe (2017), çalışmasında Gup ve Samson’ın modelleri ile geleneksel oranların ilişkisini araştırmış, finansal oranların bir kısmının modellerle ilişkili olduğunu, ancak aralarındaki korelasyonun çok düşük olduğunu başka bir ifade ile; modellerin bir firmanın finansal açıdan karakterize edilmesi için yetersiz olduğu sonucuna ulaşmıştır. Nakit akışlarını finansal başarısızlı̆̆ı tahmin etmede kullanan ilk çalışmalardan birisi Beaver’ın (1966) olsa bile, Deakin'in (1972), Largay ve Stickney (1980), Casey ve Bartczak (1985), Gombola, Haskins, Ketz ve Williams (1987) ve Rujoub, Cook ve Hay (1995) ise çalışmalarında iflas ve finansal başarısızlıkların tahmini için nakit akış oranlarını kullanmaktadırlar. Sayari ve Mugan (2013), finansal başarısızlığı nakit akışı tablosu bileşenlerini Türkiye bağlamında analiz ederek incelemiştir. Çavuş ve Başar (2020), finansal başarısızlık ölçümü Z skor ile nakit akış oranları arasında ilişkiyi inceledikleri çalışmasında, finansal başarısızlı̆̆ını öngörmede nakit akış oranlarının etkili olduğu sonucuna ulaşmıştır. Son olarak Sakarya ve Akkuş (2015) ile Yılmaz ve İçten (2018) ise çok kriterli karar verme modellerinde nakit akışına dayalı oranlar kullanılmışlardır.

Sonuç olarak, nakit akış tablosunun finansal tablo setinde yer almaya başlamasından bu yana, nakit akışları ile ilgili bilanço ve gelir tabloları analizinde kullanılan geleneksel oranlar gibi yaygın olarak kabul gören ve kullanılan bir oran seti 
oluşturulamamıştır. Ancak mevcut literatürde nakit akış oranları, temel ve diğer oranlar olmak üzere iki kategoriye ayırmaktadır. Temel oranlar, yeterlilik ve verimlilik oranlarından oluşmaktadır. Bu sınıflandırmaya ek olarak, likidite ve ödeme gücü oranları da nakit akış oran analizinin bir başka yönüdür. Yeterlilik oranları, firmaların nakit akışlarının yeterliliğini değerlendirmekte ve borçların ödenmesi ve faaliyetlerin sürdürülmesi amacıyla nakit kaynakları hakkında ileriye dönük bilgi vermektedir (Yılmaz 1999, s. 188). Verimlilik oranları ise, şirketin diğer yıllara ve diğer şirketlere göre nakit akışını ne kadar iyi ürettiğini ve firmaların varlıkları, satış ve işletme faaliyetlerini ne kadar etkili bir şekilde yönettiğini değerlendirir (Giacomino \& Mielke, 1993). Ayrıca firmaların ihtiyaç duymaları halinde diğer nakit akış oranları hesaplanabilmektedir.

\section{Belediyelerde Nakit Akış Tablosu Kullanımına Yönelik Araştırma}

Çalışmanın bu bölümünde, belediyelerde nakit akış tablosu kullanıma yönelik gerçekleştirilen araştırma hakkında bilgi verilmiştir. Bu amaçla, araştırmanın amacı ve kapsamı, veri toplama tekniği ve bulguların değerlendirilmesiyle ilgili bilgilere yer verilmiştir.

\subsection{Araștırmanın Amacı, Kapsamı ve Kısıtları}

Araştırmanın amacı, belediye birimleri tarafından nakit akış tablosu kullanım sıklı̆̆ının ve sunumunun incelenmesidir. Bu amaçla 2014 ve 2018 yılları arasında Türkiye'deki tüm il belediyeleri (51) ve büyükşehir belediyeleri (30) ile İstanbul ili ilçelerine (39) ait faaliyet raporları incelenmiş ve belediyelerin faaliyet raporlarında nakit akış tablolarına yer verip vermedikleri araştırılmıştır. Araştırmanın 2014 yılından itibaren yapılmaya başlanmasının nedeni, 2014 yılından itibaren, 6360 Sayılı Kanun ile birlikte büyükşehir belediye sayısının 30'a yükselmesi, il belediye sayısının ise 51'e düşmesidir. Araştırmanın 2018 yılında sonlandırılmasının nedeni ise, belediye birimleri tarafından 2019 faaliyet raporlarının araştırmanın yapıldığı tarih itibariyle henüz yayınlanmamış olmasıdır.

\begin{tabular}{|l|c|c|}
\hline Tablo 4: 6360 Sayılı Kanun Öncesi ve Sonrası Belediyelere İlişkin Rakamlar \\
\hline İlgili Belediye Türü & $\mathbf{6 3 6 0}$ Sayılı Kanun Öncesi & $\mathbf{6 3 6 0}$ Sayılı Kanun Sonrası \\
\hline Büyükşehir Belediyesi & $\mathbf{1 6}$ & $\mathbf{3 0}$ \\
\hline Büyükşehir İlçe Belediyesi & 143 & 519 \\
\hline İl Belediyesi & $\mathbf{6 5}$ & $\mathbf{5 1}$ \\
\hline İlçe Belediyesi & 749 & 416 \\
\hline Belde Belediyesi & 1977 & 342 \\
\hline Toplam Belediye Sayısı & 2950 & 1396 \\
\hline Kaynak: Çevre ve Şehircilik Bakanlı̆̆ı, (2012). & \\
\hline
\end{tabular}

Belediyelere ait faaliyet raporlarına ilgili belediyelerin internet sitelerinden ulaşılmış olup; araştırma kapsamında 2014 ve 2018 yıllarına ait 600 adet faaliyet raporu incelenmek istenmesine rağmen, 155 belediyenin internet sitelerinde yayınlamamış oldukları faaliyet raporlarına ulaşılamamış ve bu kısıt nedeniyle 445 adet faaliyet raporu incelenebilmiştir.

\subsection{Araştırmanın Veri Toplama Tekniği}

$\mathrm{Bu}$ çalışmada, Türkiye'de yer alan il ve büyükşehir belediyelerinin ve nüfus yoğunluğu düşünüldüğünde önemli bir yer tutan İstanbul ilçe belediyelerinin internet sitelerinde yayınladıkları faaliyet raporlarından elde edilen bilgiler analize tabi tutulmuştur. Yapılan betimsel analizde; araştırma sorusu olarak, "Büyükşehir belediyeleri faaliyet raporlarında nakit akış tablolarına yer vermektedir", "Il belediyeleri faaliyet raporlarında nakit akıs tablolarına yer vermektedir" ve "İstanbul ilçe belediyeleri faaliyet raporlarında nakit akış tablolarına yer vermektedir" ifadelerinin doğruluğu araştırılmaktadır.

\subsection{Araştırmanı Bulguları}

51 il ve 30 büyükşehir belediyelerinin faaliyet raporları içerik analizine tabi tutularak incelendiğinde, il ve büyükşehir belediyelerinin faaliyet raporlarında, nakit akış tablosu sunumuna yer vermedikleri tespit edilmiş olup; bazı belediye birimlerinin faaliyet raporunu internet sitesinde yayımlamadığı görülmüştür. Araştırmaya ilişkin analiz sonuçları Tablo 5 'te yer almaktadır. 
Tablo 5: İl Belediyesi ve Büyükşehir Belediyeleri Nakit Akış Tablosu Sunumu

\begin{tabular}{|c|c|c|c|c|c|c|c|c|c|c|c|}
\hline ŞEHİR & 2014 & 2015 & 2016 & 2017 & 2018 & ŞEHİR & 2014 & 2015 & 2016 & 2017 & 2018 \\
\hline ADANA & $\mathrm{X}$ & $\mathrm{X}$ & $\mathrm{X}$ & $\mathrm{X}$ & $\mathrm{X}$ & K.MARAŞ & $\mathrm{X}$ & $\mathrm{X}$ & $\mathrm{X}$ & $\mathrm{X}$ & $\mathrm{X}$ \\
\hline ADIYAMAN & $\mathrm{X}$ & $\mathrm{X}$ & $\mathrm{X}$ & $\mathrm{X}$ & 0 & KARABÜK & $\mathrm{X}$ & $\mathrm{X}$ & $\mathrm{X}$ & $\mathrm{X}$ & $\mathrm{X}$ \\
\hline ARDAHAN & 0 & 0 & 0 & 0 & 0 & KARAMAN & $\mathrm{X}$ & $\mathrm{X}$ & $\mathrm{X}$ & $\mathrm{X}$ & $\mathrm{X}$ \\
\hline AFYON & 0 & $\mathrm{X}$ & $\mathrm{X}$ & $\mathrm{X}$ & $\mathrm{X}$ & KARS & 0 & $\mathrm{X}$ & $\mathrm{X}$ & $\mathrm{X}$ & $\mathrm{X}$ \\
\hline AĞRI & 0 & 0 & 0 & 0 & 0 & KASTAMONU & 0 & $\mathrm{X}$ & $\mathrm{X}$ & $\mathrm{X}$ & $\mathrm{X}$ \\
\hline AKSARAY & 0 & 0 & 0 & 0 & $\mathrm{X}$ & KAYSERİ & 0 & $\mathrm{X}$ & $\mathrm{X}$ & $\mathrm{X}$ & $\mathrm{X}$ \\
\hline AMASYA & 0 & 0 & 0 & $\mathrm{X}$ & 0 & KRIKKALE & $\mathrm{X}$ & $\mathrm{X}$ & 0 & 0 & 0 \\
\hline ANKARA & $\mathrm{X}$ & $\mathrm{X}$ & $\mathrm{X}$ & $\mathrm{X}$ & $\mathrm{X}$ & KIRKLARELI & 0 & $\mathrm{X}$ & $\mathrm{X}$ & $\mathrm{X}$ & 0 \\
\hline ANTALYA & $\mathrm{X}$ & $\mathrm{X}$ & $\mathrm{X}$ & $\mathrm{X}$ & $\mathrm{X}$ & KIRŞEHİR & $\mathrm{X}$ & $\mathrm{X}$ & 0 & $\mathrm{X}$ & $\mathrm{X}$ \\
\hline ARTVIN & 0 & 0 & 0 & 0 & 0 & KíLís & $\mathrm{X}$ & 0 & $\mathrm{X}$ & $\mathrm{X}$ & $\mathrm{X}$ \\
\hline AYDIN & $\mathrm{X}$ & $\mathrm{X}$ & $\mathrm{X}$ & $\mathrm{X}$ & $\mathrm{X}$ & KOCAELI & $\mathrm{X}$ & $\mathrm{X}$ & $\mathrm{X}$ & $\mathrm{X}$ & $\mathrm{X}$ \\
\hline BALIKESIIR & $\mathrm{X}$ & $\mathrm{X}$ & $\mathrm{X}$ & $\mathrm{X}$ & $\mathrm{X}$ & KONYA & 0 & $\mathrm{X}$ & $\mathrm{X}$ & $\mathrm{X}$ & $\mathrm{X}$ \\
\hline BARTIN & $\mathrm{X}$ & $\mathrm{X}$ & $\mathrm{X}$ & $\mathrm{X}$ & $\mathrm{X}$ & KÜTAHYA & $\mathrm{X}$ & $\mathrm{X}$ & $\mathrm{X}$ & $\mathrm{X}$ & $\mathrm{X}$ \\
\hline BATMAN & 0 & 0 & 0 & 0 & 0 & MALATYA & 0 & 0 & 0 & $\mathrm{X}$ & $\mathrm{X}$ \\
\hline BAYBURT & 0 & 0 & 0 & 0 & 0 & MANISA & 0 & 0 & 0 & 0 & 0 \\
\hline BİLECİK & $\mathrm{X}$ & $\mathrm{X}$ & $\mathrm{X}$ & $\mathrm{X}$ & $\mathrm{X}$ & MARDIN & 0 & 0 & 0 & $\mathrm{X}$ & 0 \\
\hline BINGÖL & $\mathrm{X}$ & $\mathrm{X}$ & $\mathrm{X}$ & $\mathrm{X}$ & $\mathrm{X}$ & MERSİN & $\mathrm{X}$ & $\mathrm{X}$ & $\mathrm{X}$ & $\mathrm{X}$ & $\mathrm{X}$ \\
\hline BİTLISS & 0 & 0 & 0 & 0 & 0 & MUĞLA & $\mathrm{X}$ & $\mathrm{X}$ & $\mathrm{X}$ & $\mathrm{X}$ & $\mathrm{X}$ \\
\hline BOLU & 0 & $\mathrm{X}$ & $\mathrm{X}$ & $\mathrm{X}$ & $\mathrm{X}$ & MUŞ & 0 & 0 & 0 & 0 & 0 \\
\hline BURDUR & 0 & 0 & 0 & $\mathrm{X}$ & 0 & NEVSEHİR & 0 & 0 & $\mathrm{X}$ & $\mathrm{X}$ & $\mathrm{X}$ \\
\hline BURSA & $\mathrm{X}$ & $\mathrm{X}$ & $\mathrm{X}$ & $\mathrm{X}$ & $\mathrm{X}$ & NİĞDE & 0 & 0 & 0 & 0 & $\mathrm{X}$ \\
\hline ÇANAKKALE & $\mathrm{X}$ & $\mathrm{X}$ & $\mathrm{X}$ & $\mathrm{X}$ & $\mathrm{X}$ & ORDU & $\mathrm{X}$ & $\mathrm{X}$ & $\mathrm{X}$ & $\mathrm{X}$ & $\mathrm{X}$ \\
\hline ÇANKIRI & 0 & 0 & 0 & 0 & 0 & OSMANIYE & 0 & 0 & 0 & $\mathrm{X}$ & 0 \\
\hline ÇORUM & $\mathrm{X}$ & $\mathrm{X}$ & $\mathrm{X}$ & $\mathrm{X}$ & $\mathrm{X}$ & RİZE & $\mathrm{X}$ & $\mathrm{X}$ & $\mathrm{X}$ & 0 & $\mathrm{X}$ \\
\hline DENIZZLI & $\mathrm{X}$ & $\mathrm{X}$ & $\mathrm{X}$ & $\mathrm{X}$ & $\mathrm{X}$ & SAKARYA & $\mathrm{X}$ & $\mathrm{X}$ & $\mathrm{X}$ & $\mathrm{X}$ & $\mathrm{X}$ \\
\hline DİYARBAKIR & 0 & 0 & 0 & $\mathrm{X}$ & 0 & SAMSUN & $\mathrm{X}$ & $\mathrm{X}$ & $\mathrm{X}$ & $\mathrm{X}$ & $\mathrm{X}$ \\
\hline DÜZCE & $\mathrm{X}$ & $\mathrm{X}$ & $\mathrm{X}$ & $\mathrm{X}$ & $X$ & SiIRT & 0 & 0 & 0 & 0 & 0 \\
\hline EDİRNE & $\mathrm{X}$ & $\mathrm{X}$ & $\mathrm{X}$ & $\mathrm{X}$ & $\mathrm{X}$ & SINOP & $\mathrm{X}$ & $\mathrm{X}$ & $\mathrm{X}$ & $\mathrm{X}$ & $\mathrm{X}$ \\
\hline ELAZIĞ & $\mathrm{X}$ & $\mathrm{X}$ & $\mathrm{X}$ & $\mathrm{X}$ & $\mathrm{X}$ & SIVAS & $\mathrm{X}$ & $\mathrm{X}$ & $\mathrm{X}$ & $\mathrm{X}$ & $\mathrm{X}$ \\
\hline ERZINCAAN & $\mathrm{X}$ & $\mathrm{X}$ & $\mathrm{X}$ & $\mathrm{X}$ & $\mathrm{X}$ & URFA & 0 & $\mathrm{X}$ & $\mathrm{X}$ & $\mathrm{X}$ & $\mathrm{X}$ \\
\hline ERZURUM & $\mathrm{X}$ & $\mathrm{X}$ & $\mathrm{X}$ & $\mathrm{X}$ & $\mathrm{X}$ & ŞIRNAK & 0 & 0 & 0 & 0 & 0 \\
\hline ESKIŞEHİR & $\mathrm{X}$ & $\mathrm{X}$ & $\mathrm{X}$ & $\mathrm{X}$ & $\mathrm{X}$ & TEKİRDAĞ & $\mathrm{X}$ & $\mathrm{X}$ & $\mathrm{X}$ & $\mathrm{X}$ & $\mathrm{X}$ \\
\hline GAZİANTEP & 0 & $\mathrm{X}$ & $\mathrm{X}$ & $\mathrm{X}$ & $\mathrm{X}$ & TOKAT & 0 & 0 & 0 & 0 & 0 \\
\hline GÍRESUN & $\mathrm{X}$ & $\mathrm{X}$ & $\mathrm{X}$ & $\mathrm{X}$ & $\mathrm{X}$ & TRABZON & $\mathrm{X}$ & $\mathrm{X}$ & $\mathrm{X}$ & $\mathrm{X}$ & $\mathrm{X}$ \\
\hline GÜMÜŞHANE & 0 & 0 & 0 & 0 & 0 & TUNCELİ & 0 & 0 & 0 & 0 & 0 \\
\hline HAKKARİ & 0 & 0 & 0 & 0 & 0 & UŞAK & $\mathrm{X}$ & $\mathrm{X}$ & $\mathrm{X}$ & $\mathrm{X}$ & $\mathrm{X}$ \\
\hline HATAY & 0 & $\mathrm{X}$ & $\mathrm{X}$ & $\mathrm{X}$ & $\mathrm{X}$ & VAN & 0 & 0 & 0 & $\mathrm{X}$ & $\mathrm{X}$ \\
\hline IĞDIR & 0 & 0 & 0 & 0 & 0 & YALOVA & 0 & $\mathrm{X}$ & 0 & $\mathrm{X}$ & $\mathrm{X}$ \\
\hline ISPARTA & 0 & 0 & 0 & $\mathrm{X}$ & $\mathrm{X}$ & YOZGAT & 0 & 0 & 0 & 0 & 0 \\
\hline İSTANBUL & $\mathrm{X}$ & $\mathrm{X}$ & $\mathrm{X}$ & $\mathrm{X}$ & $\mathrm{X}$ & ZONGULDAK & $\mathrm{X}$ & $\mathrm{X}$ & $\mathrm{X}$ & $\mathrm{X}$ & $\mathrm{X}$ \\
\hline İZMİR & $\mathrm{X}$ & $\mathrm{X}$ & $\mathrm{X}$ & $\mathrm{X}$ & $\mathrm{X}$ & & & & & & \\
\hline
\end{tabular}

Tablo 5 incelendiğinde analiz sonuçlarına göre; "Büyükşehir belediyeleri faaliyet raporlarında nakit akış tablolarına yer vermektedir" ve "il belediyeleri faaliyet raporlarında nakit akış tablolarına yer vermektedir" ifadelerinin geçersiz olduğu anlaşılmaktadır. Başka bir ifadeyle, il belediyeleri ve büyükşehir belediyelerinin faaliyet raporlarında, mali tablolara ilişkin bölümlerde nakit akış tablosuna ilişkin bilgilere rastlanmamıştır.

İstanbul ili, 39 ilçe belediyesinin faaliyet raporları içerik analizine tabi tutularak incelendiğinde, nakit akış tablosunu sunumunun 3 belediye tarafından gerçekleştirildiği sonucuna rastlanmış, diğer belediye birimlerinin nakit akış tablosu sunumuna yer vermedikleri tespit edilmiştir. Araştırmaya ilişkin analiz sonuçları Tablo 6’te yer almaktadır. 


\begin{tabular}{|c|c|c|c|c|c|c|c|c|c|c|c|}
\hline İLÇELER & 2014 & 2015 & 2016 & 2017 & 2018 & İLÇELER & 2014 & 2015 & 2016 & 2017 & 2018 \\
\hline ADALAR & $\mathrm{X}$ & $\mathrm{X}$ & $\mathrm{X}$ & $\mathrm{X}$ & $\mathrm{X}$ & GAZİOSMANPAŞA & $\mathrm{X}$ & $\mathrm{X}$ & $\mathrm{X}$ & $\mathrm{X}$ & $\mathrm{X}$ \\
\hline ARNAVUTKÖY & $\mathrm{X}$ & $\mathrm{X}$ & $\mathrm{X}$ & $\mathrm{X}$ & $\mathrm{X}$ & GÜNGÖREN & $\mathrm{X}$ & $\mathrm{X}$ & $\mathrm{X}$ & $\mathrm{X}$ & $\mathrm{X}$ \\
\hline ATAŞEHIIR & $\mathrm{X}$ & $\mathrm{X}$ & $\mathrm{X}$ & $\mathrm{X}$ & $\mathrm{X}$ & KADIKÖY & $\mathrm{X}$ & $\mathrm{X}$ & $\mathrm{X}$ & $\mathrm{X}$ & $\mathrm{X}$ \\
\hline AVCILAR & $\mathrm{X}$ & $\mathrm{X}$ & $\mathrm{X}$ & $\mathrm{X}$ & $\mathrm{X}$ & KAĞITHANE & $\checkmark$ & $\checkmark$ & $\checkmark$ & $\checkmark$ & $\checkmark$ \\
\hline BAĞCILAR & $\mathrm{X}$ & $\mathrm{X}$ & $\mathrm{X}$ & $\mathrm{X}$ & $\mathrm{X}$ & KARTAL & $\mathrm{X}$ & $\mathrm{X}$ & $\mathrm{X}$ & $X$ & $\mathrm{X}$ \\
\hline BAHÇELIEVLER & $\mathrm{X}$ & $\mathrm{X}$ & $\mathrm{X}$ & $\mathrm{X}$ & $\mathrm{X}$ & KÜÇÜKÇEKMECE & 0 & $\mathrm{X}$ & $\mathrm{X}$ & $\mathrm{X}$ & $\mathrm{X}$ \\
\hline BAKIRKÖY & $\mathrm{X}$ & $\mathrm{X}$ & $X$ & $\mathrm{X}$ & $\mathrm{X}$ & MALTEPE & $X$ & $\mathrm{X}$ & $X$ & $X$ & $X$ \\
\hline BAŞAKŞEHİR & 0 & 0 & 0 & $\mathrm{X}$ & 0 & PENDİK & $\mathrm{X}$ & $\mathrm{X}$ & $\mathrm{X}$ & $\mathrm{X}$ & $\mathrm{X}$ \\
\hline BAYRAMPAŞA & $X$ & $\mathrm{X}$ & $\mathrm{X}$ & $\mathrm{X}$ & $X$ & SANCAKTEPE & $\mathrm{X}$ & $\mathrm{X}$ & $\mathrm{X}$ & $X$ & $X$ \\
\hline BEŞİKTAŞ & $\mathrm{X}$ & $\mathrm{X}$ & $\mathrm{X}$ & $\mathrm{X}$ & $\mathrm{X}$ & SARIYER & $\mathrm{X}$ & $\mathrm{X}$ & $\mathrm{X}$ & $\checkmark$ & $\checkmark$ \\
\hline BEYKOZ & $\mathrm{X}$ & $\mathrm{X}$ & $\mathrm{X}$ & $\mathrm{X}$ & 0 & SÍLIVRI & $\mathrm{X}$ & $\mathrm{X}$ & $\mathrm{X}$ & $\mathrm{X}$ & $\mathrm{X}$ \\
\hline BEYLİKDÜZÜ & $\mathrm{X}$ & $\mathrm{X}$ & $\mathrm{X}$ & $\mathrm{X}$ & $\mathrm{X}$ & SULTANBEYLI & $\mathrm{X}$ & $\mathrm{X}$ & $\mathrm{X}$ & $\mathrm{X}$ & $\mathrm{X}$ \\
\hline BEYOĞLU & $X$ & $\checkmark$ & $\checkmark$ & $\checkmark$ & $\checkmark$ & SULTANGAZI & $\mathrm{X}$ & $X$ & $X$ & $X$ & $X$ \\
\hline BÜYÜKÇEKMECE & $\mathrm{X}$ & $X$ & $X$ & $\mathrm{X}$ & $\mathrm{X}$ & ŞİLE & $\mathrm{X}$ & $\mathrm{X}$ & $X$ & $\mathrm{X}$ & $X$ \\
\hline ÇATALCA & 0 & 0 & $X$ & 0 & $\mathrm{X}$ & ŞİşLI & $\mathrm{X}$ & $\mathrm{X}$ & $X$ & $\mathrm{X}$ & $X$ \\
\hline ÇEKMEKÖY & $\mathrm{X}$ & $\mathrm{X}$ & $\mathrm{X}$ & $\mathrm{X}$ & $X$ & TUZLA & $\mathrm{X}$ & $\mathrm{X}$ & $X$ & $\mathrm{X}$ & $X$ \\
\hline ESENLER & $\mathrm{X}$ & $X$ & $\mathrm{X}$ & 0 & $\mathrm{X}$ & ÜMRANIYYE & $\mathrm{X}$ & $\mathrm{X}$ & $\mathrm{X}$ & $\mathrm{X}$ & $\mathrm{X}$ \\
\hline ESENYURT & $\mathrm{X}$ & $\mathrm{X}$ & $\mathrm{X}$ & $\mathrm{X}$ & $\mathrm{X}$ & ÜSKÜDAR & $\mathrm{X}$ & $\mathrm{X}$ & $\mathrm{X}$ & $\mathrm{X}$ & $\mathrm{X}$ \\
\hline EYÜPSULTAN & $\mathrm{X}$ & $\mathrm{X}$ & $X$ & $\mathrm{X}$ & $\mathrm{X}$ & ZEYTINBURNU & $X$ & $\mathrm{X}$ & $\mathrm{X}$ & $\mathrm{X}$ & $X$ \\
\hline FATİH & $\mathrm{X}$ & $\mathrm{X}$ & $\mathrm{X}$ & $\mathrm{X}$ & $\mathrm{X}$ & & & & & & \\
\hline \multicolumn{12}{|c|}{$\begin{array}{|ll|}\mathbf{X} & : \text { Faaliyet raporunda nakit akış tablosuna yer vermemekte, } \\
\mathbf{0} & : \text { İnternet sitesinde faaliyet raporuna yer vermemekte, } \\
\checkmark & : \text { Faaliyet raporunda nakit akış tablosuna yer vermekte. } \\
\end{array}$} \\
\hline
\end{tabular}

Tablo 6 incelendiğinde analiz sonuçlarına göre; "İstanbul ilçe belediyeleri faaliyet raporlarında nakit akış tablolarına yer vermektedir" ifadesinin geçersiz olduğu anlaşılmaktadır. Başka bir ifadeyle, İstanbul ili, ilçe belediyelerinin faaliyet raporlarında, mali tablolara ilişkin bölümlerde nakit akış tablolarına büyük bir oranda yer vermedikleri, sadece Beyoğlu, Kağıthane ve Sarıyer belediyelerinin faaliyet raporlarında nakit akış tablosuna yer verdikleri görülmektedir. Beyoğlu belediyesi nakit akış tablosunun sunumunda, DMS 2 Nakit Akış Tabloları Standardına uygun bir şekilde nakit akışlarını 3 bölümde sunarken, Sarıyer belediyesinin nakit akış tablosu sadece nakit girişleri ve nakit çıkışları olarak sınıflamakta, DMS 2'de belirtilen sınıflandırmaya tabi tutmamaktadır. Kağıthane belediyesi ise; nakit akış tablosunu DMS 2 çerçevesinde 3 bölümde sunmakta ancak, yatırım ve finansman faaliyetlerinden sağlanan nakit kısımlarına ilişkin hiçbir tutarın yazılmaması, araştırmada dikkat çeken başka bir bulgu olarak karşımıza çıkmaktadır.

\section{Belediyelerde Nakit Akış Tablosunun Düzenlemesi ve Analizine Yönelik Bir Uygulama}

Bu uygulamanın amacı; çalışmada araştırmanın bulguları kısmında belirtilen faaliyet raporları içerik analizi sonuçlarına göre, belediyeler tarafından yeterince uygulamasına yer verilmeyen nakit akış tablosunun, belediyelerde kullanımının yaygınlaştırılması ve nakit akış analizlerinin belediyeler üzerinde uygulanabilirliğinin araştırılmasıdır.

Bu amaçla nakit akış tablosu düzenlemesi, İstanbul ili Beylikdüzü ilçe belediyesi 2017-2018-2019 yıllarına ilişkin mali veriler kullanılarak gerçekleştirilmiştir. Tablo 1'de belirtilen hesap planı ve nakit akış tablosu eşleştirmesi dikkate alınarak, Beylikdüzü belediyesinin ilgili dönem mizan ve mali verilerinin incelenmesi ile elde edilen verilere göre, belediyeye ait 2017-2019 dönemlerine ilişkin karşılaştırmalı nakit akış tablosuna Tablo 7’te yer verilmiştir. 
Tablo 7: İstanbul İli Beylikdüzü İlçesi 2017-2018-2019 Dönemi Karşılaştırmalı Nakit Akış Tabloları

\begin{tabular}{|c|c|c|c|}
\hline \multicolumn{4}{|c|}{ BEYLIKKDÜZÜ BELEDİYESİ } \\
\hline \multicolumn{4}{|l|}{ NAKİT AKIŞ TABLOSU } \\
\hline NAKİT AKIŞLARI & 2017 YILI & 2018 YILI & 2019 YILI \\
\hline \multicolumn{4}{|l|}{ Faaliyetlerden Sağlanan Nakit Akışları } \\
\hline A- Faaliyetlerden Sağlanan Nakit Girişleri & $526.188 .632,58$ & $547.445 .935,64$ & $504.028 .735,17$ \\
\hline 01- Vergiler & $146.793 .048,95$ & $161.462 .281,07$ & $150.658 .021,89$ \\
\hline 02- Vergi D1ş1 Gelirler & 0,00 & 0,00 & 0,00 \\
\hline 03- Teşebbüs ve Mülkiyet Gelirleri & $18.892 .712,00$ & $18.250 .871,14$ & $19.374 .125,59$ \\
\hline 04- Alınan Bağış ve Yardımlar ile Özel Gelirler & $867.179,09$ & $18.358,02$ & $14.842,63$ \\
\hline 05- Diğer Gelirler & $142.030 .631,45$ & $205.890 .201,17$ & $244.095 .158,44$ \\
\hline 11- Değer ve Miktar Değiş̧imleri Gelirleri & 0,00 & 0,00 & $377.394,66$ \\
\hline Diğer Nakit Girişleri (330) & $16.132 .434,52$ & $10.841 .178,57$ & $16.945 .194,37$ \\
\hline Diğger Nakit Girişleri (333) & $201.472 .626,57$ & $150.983 .045,67$ & $72.563 .997,59$ \\
\hline B- Faaliyetlerden Sağlanan Nakit Çıkışları & $470.600 .264,87$ & $527.792 .662,04$ & $446.603 .034,90$ \\
\hline 01- Personel Giderleri & $48.244 .177,78$ & $54.377 .864,06$ & $60.208 .853,69$ \\
\hline 02- Sosyal Güvenlik Kurumlarına Devlet Primi Giderleri & $6.707 .583,76$ & $7.533 .706,77$ & $8.269 .605,43$ \\
\hline 03- Mal ve Hizmet Alım Giderleri & $187.121 .299,36$ & $217.169 .962,30$ & $188.922 .244,65$ \\
\hline 04- Faiz Giderleri & $12.614 .127,16$ & $41.751 .293,91$ & $9.228 .671,15$ \\
\hline 05- Cari Transferler & $46.582 .172,13$ & $53.290 .561,92$ & $57.568 .852,97$ \\
\hline 07- Sermaye Transferleri & $1.071 .965,63$ & $1.113 .021,10$ & $2.059 .812,79$ \\
\hline Diğer Nakit Çıkışları (330) & $14.928 .511,76$ & $11.002 .681,73$ & $5.995 .623,47$ \\
\hline Diğer Nakit Çıkışları (333) & $153.330 .427,29$ & $141.553 .570,25$ & $114.349 .370,75$ \\
\hline C-Faaliyetlerden Sağlanan Net Nakit Girişi (A-B) & $55.588 .367,71$ & $19.653 .273,60$ & $57.425 .700,27$ \\
\hline \multicolumn{4}{|l|}{ Yatırımlardan Sağlanan Nakit Akışları } \\
\hline D- Mali Olmayan Duran Varlık Alımları & $105.373 .248,56$ & $97.495 .120,38$ & $88.662 .220,79$ \\
\hline 01- Tesis ve Ekipman Alımına Yönelik Nakit Çıkışları (253-254-255-260-294) & $2.127 .736,86$ & $8.765 .048,59$ & $1.869 .049,02$ \\
\hline $\begin{array}{l}\text { 03- Diğer Yatırım Faaliyetlerinden Kaynaklanan Nakit Çıkışları } \\
(150-250-251-252-258)\end{array}$ & $103.245 .511,70$ & $88.730 .071,79$ & $86.793 .171,77$ \\
\hline E- Mali Olmayan Duran Varlık Satışları & $54.191 .856,16$ & $6.302 .166,77$ & $2.941 .880,00$ \\
\hline $\begin{array}{l}\text { 01- Tesis ve Ekipmanların Satışından Kaynaklanan Nakit Girişleri (800-06-1 / } \\
\text { 800-06-2) }\end{array}$ & $54.191 .856,16$ & $6.302 .166,77$ & 2.941.880,00 \\
\hline 03- Diğer Yatırım Faaliyetlerinden Kaynaklanan Nakit Girişleri (800-06-9) & 0,00 & 0,00 & 0,00 \\
\hline F- Yatırımlardan Sağlanan Net Nakit Çıkışı (E-D) & $-51.181 .392,40$ & $-91.192 .953,61$ & $-85.720 .340,79$ \\
\hline G- Nakit Açık / Fazlası (C+F) & $4.406 .975,31$ & $-71.539 .680,01$ & $-28.294 .640,52$ \\
\hline \multicolumn{4}{|l|}{ Finansman Faaliyetlerinden Sağlanan Nakit Akıșları } \\
\hline H- Nakit Dışında Net Mali Varlık Edinimleri & $15.952 .793,46$ & $21.247 .521,85$ & $32.448 .123,24$ \\
\hline $\begin{array}{l}\text { Alınan Borçların Geri Ödenmesinden Kaynaklanan Nakit Çıkışları } \\
(300-303-310)\end{array}$ & $15.952 .793,46$ & $21.247 .521,85$ & $32.448 .123,24$ \\
\hline I- Net Yabancı Kaynak Artışları & $64.964 .836,23$ & $69.012 .042,77$ & $78.264 .520,92$ \\
\hline Borçlanmadan Kaynaklanan Nakit Girişleri (300-303-310-400-403-410) & $28.000 .000,00$ & $20.000 .000,00$ & $30.500 .000,00$ \\
\hline $\begin{array}{l}\text { Diğer Finansman Faaliyetlerinden Kaynaklanan Nakit Girişleri (Bir Önceki } \\
\text { Yildan Devreden Banka Mevcudu) }\end{array}$ & $36.964 .836,23$ & $49.012 .042,77$ & $47.764 .520,92$ \\
\hline K- Finansman Faaliyetlerinden Sağlanan Net Nakit Girişleri (I-H) & 49.012.042,77 & $47.764 .520,92$ & $45.816 .397,68$ \\
\hline L- Nakit Stokundaki Net Değişim $(\mathrm{G}+\mathrm{K})$ & $53.419 .018,08$ & $-23.775 .159,09$ & $17.521 .757,16$ \\
\hline Bankanın bir sonraki yıla devri & $16.692 .268,48$ & $12.335 .650,41$ & $11.106 .258,88$ \\
\hline Bütçe Emanetinin (N Y1lı) bir sonraki yıla devri & $92.199 .407,21$ & $159.482 .978,16$ & $197.659 .639,68$ \\
\hline
\end{tabular}

\subsection{Belediyelere Ait Nakit Akış Tablosu'nun Nakit Akışlarının Sağlandığı Faaliyetler Yöntemine Göre Analizi}

Çalışmada, Beylikdüzü belediyesine ait hazırlanan nakit akış tablosu ve faaliyet raporlarında nakit akış tablosuna yer veren belediyelerin nakit akış profilleri, nakit akışlarının sağlandığ faaliyetler yöntemi ile analize tabi tutulmuş ve uygulanabilirliği araştırılmıştır. 
Uygulamanın yapıldığı Beylikdüzü belediyesinin nakit akış tablosundaki bölümlerinin, pozitif/negatif olması durumuna göre yapılan Nakit Akışlarının Sağlandı̆̆ı Faaliyetler Analiz yönteminin sonuçları Tablo 8'de yer almaktadır.

\begin{tabular}{|c|c|c|c|}
\hline Tablo 8: Beylikdüzü Belediyesi Nakit Akışlarının Sağlandığı Faaliyetler Yöntemi Analiz Sonuçları \\
\hline & $\begin{array}{c}\text { Faaliyetlerden Sağlanan Net } \\
\text { Nakit Akışları }\end{array}$ & $\begin{array}{c}\text { Yatırımlardan Sağlanan Net Nakit } \\
\text { Akışları }\end{array}$ & $\begin{array}{c}\text { Finansmandan Faaliyetlerinden } \\
\text { Sağlanan Net Nakit Akışı }\end{array}$ \\
\hline 2017 & $(+)$ & $(-)$ & $(+)$ \\
\hline 2018 & $(+)$ & $(-)$ & $(+)$ \\
\hline 2019 & $(+)$ & $(-)$ & $(+)$ \\
\hline
\end{tabular}

Tablo 8 incelendiğinde, Beylikdüzü belediyesinin 2017, 2018 ve 2019'a ait nakit akışlarının tamamının Model 4'e uygun olduğu tespit edilmiştir. Bu sonuç, Beylikdüzü belediyesi için büyüyen belediye nitelemesi yapılarak yorumlanabilir.

Belediyelere ait faaliyet raporlarının içerik analizinde tespit edilen Beyoğlu belediyesine ait nakit akış tabloları üzerinde, nakit akışlarının sağlandığı faaliyetler analiz tekniği uygulama sonuçlarına Tablo 9'da yer verilmiştir.

\begin{tabular}{|c|c|c|c|}
\hline \multicolumn{2}{|c|}{ Tablo 9: Beyoğlu Belediyesi Nakit Akışlarının Sağlandığı Faaliyetler Yöntemi Analiz Sonuçları } \\
\hline & $\begin{array}{c}\text { Faaliyetlerden Sağlanan Net } \\
\text { Nakit Akışları }\end{array}$ & $\begin{array}{c}\text { Yatırımlardan Sağlanan Net Nakit } \\
\text { Akışları }\end{array}$ & $\begin{array}{c}\text { Finansmandan Faaliyetlerinden } \\
\text { Sağlanan Net Nakit Akışı }\end{array}$ \\
\hline 2015 & $(-)$ & $(-)$ & $(+)$ \\
\hline 2016 & $(-)$ & $(-)$ & $(+)$ \\
\hline 2017 & $(-)$ & $(-)$ & $(+)$ \\
\hline 2018 & $(-)$ & $(-)$ & $(+)$ \\
\hline
\end{tabular}

Tablo 9 incelendiğinde, Beyoğlu belediyesinin 2016, 2017 ve 2018'e ait nakit akışlarının tamamının Model 6'ya uygun olduğu tespit edilmiştir. Bu sonuç, Beyoğlu belediyesi için genç belediye/giriş yaşam döngüsünde yer almakta olan belediye nitelemesi yapılarak yorumlanabilir.

İçerik analizine tabi tutulan belediyelere ait faaliyet raporlarında, nakit akış tablosuna yer verildiği tespit edilen Sarıyer ve Kağıthane belediyeleri üzerinde uygulama gerçekleştirilememiştir. Sarıyer belediyesinin nakit akış tablosunda sadece nakit giriş ve çıkış şeklinde nakit akışına yer vermesi, DMS 2 Standardında belirtildiği üzere 3 bölüm (Faaliyetler-YatırımFinansman) olarak nakit akışına yer vermemesi; Kağıthane belediyesi için ise, yatırım ve finansman faaliyetleri bölümünde her hangi bir tutara yer verilmemesi söz konusu olduğu için, ilgili belediyeler bu uygulamaya dahil edilememiştir.

\subsection{Belediyelere Ait Nakit Akış Tablosu'nun Oran Analizi Yöntemine Göre Analizi}

Literatürdeki kullanılan temel ve diğer nakit akış oranlarından belediyelere uyarlanabilen nakit akış oranları Tablo 10'da sunulmaktadır. Aynı zamanda Tablo 10'da nakit akış tablosu uygulamasının gerçekleştiği Beylikdüzü belediyesine ait nakit akışlarının oran analizi sonuçlarına da yer verilmektedir. 


\begin{tabular}{|c|c|c|c|c|c|}
\hline \multirow[t]{2}{*}{ Yeterlilik Oranları } & \multirow[t]{2}{*}{ Açıklama } & \multicolumn{3}{|c|}{$\begin{array}{l}\text { Beylikdüzü Belediyesi Oran } \\
\text { Analizi Sonuçları }\end{array}$} & \multirow{2}{*}{$\begin{array}{c}\text { Arzu } \\
\text { Edilen } \\
\text { Değer }\end{array}$} \\
\hline & & 2017 & 2018 & 2019 & \\
\hline Cari Borç Karşılama Oranı & Faaliyetlerden Sağlanan Nakit / Kısa Vadeli Borçlar & 0,20 & 0,06 & 0,14 & Yüksek \\
\hline Nakit Akışı Borç Oranı & Faaliyetlerden Sağ. Nakit / Toplam Borç & 0,15 & 0,040 & 0,11 & Yüksek \\
\hline Dış Finansman Endeksi Oranı & $\begin{array}{l}\text { Finansman Faal. Sağ. Nakit / Faaliyetlerden Sağ. } \\
\text { Nakit }\end{array}$ & 0,88 & 2,43 & 0,79 & Düşük \\
\hline Verimlilik Oranları & Açıklama & & & & \\
\hline Gelir Kalitesi & Faaliyetlerden Sağ. Nakit / Faaliyet Sonucu & $-1,04$ & $-0,44$ & 1,23 & Yüksek \\
\hline Varlıkların Nakit Getirisi & Faaliyetlerden Sağ. Nakit / Toplam Varlıklar & 0,06 & 0,02 & 0,06 & Yüksek \\
\hline Özkaynaklar Nakit Akış Oranı & Faaliyetlerden Sağ. Nakit / Özkaynak & 0,11 & 0,04 & 0,13 & Yüksek \\
\hline $\begin{array}{l}\text { Nakit Akışlarının } \\
\text { Özkaynaklara Oranı }\end{array}$ & $\begin{array}{l}\text { (Faaliyetlerden+Yatırımdan+Finansmandan } \\
\text { Sağlanan Nakit) / Özkaynak }\end{array}$ & 0,11 & $-0,05$ & 0,04 & Yüksek \\
\hline Genel Nakit Akış Oranı & $\begin{array}{l}\text { Faaliyetlerden Sağ. Nakit / Finansman ve Yatırım } \\
\text { Faal. için Nakit Çıkışı }\end{array}$ & 0,45 & 0,16 & 0,47 & Yüksek \\
\hline Diğer Nakit Akış Oranları & Açıklama & & & & \\
\hline Faiz Karşılama Oranı & $\begin{array}{l}\text { (Faaliyetlerden Sağ. Nakit + Ödenen Faiz) / Ödenen } \\
\text { Faiz }\end{array}$ & 5,40 & 1,47 & 7,22 & Yüksek \\
\hline İşletme ve Finansman Etkinliği & $\begin{array}{l}\text { Faaliyetlerden Sağ. Nakit / Finansman Faal. Sağ. } \\
\text { Nakit }\end{array}$ & 1,13 & 0,41 & 1,25 & Yüksek \\
\hline İşletme ve Yatırım Etkinliği & Faaliyetlerden Sağ. Nakit / Yatırım Faal. Sağ. Nakit & $-1,08$ & $-0,21$ & $-0,66$ & Yüksek \\
\hline Yatırım / Finans Oranı & $\begin{array}{l}\text { Yatırım Faal. Sağ. Nakit / Finansman Faal. Sağ. } \\
\text { Nakit }\end{array}$ & $-1,04$ & $-1,90$ & $-1,87$ & Yüksek \\
\hline Duran Varlık Nakit Akışı Oranı & Faaliyetlerden Sağ. Nakit / Duran Varlıklar & 0,07 & 0,02 & 0,07 & Yüksek \\
\hline $\begin{array}{l}\text { İşletme Sermayesi Nakit Akış1 } \\
\text { Oranı }\end{array}$ & Faaliyetlerden Sağ. Nakit / Dönen Varlıklar & 0,50 & 0,19 & 0,51 & Yüksek \\
\hline
\end{tabular}

Tablo 10'da yer alan oranlar incelendiğinde; 2017 yılı ile 2019 yılı nakit akış verilerinin büyük bir oranda benzer olduğu tespit edilmiştir. 2018 yılına bakıldığında ise, belediyenin Dış Finansman Endeksi Oranının \% 243’lük bir değer olarak karşımıza çıktığı görülmektedir. Bu bulgu belediyenin 2018 yılında aşırı borçlanmaya yöneldiği şeklinden yorumlanmaktadır. Bu borçlanma ile birlikte 2018 yılı için, Cari Borç Karşılama oranı \% 6’lara, Nakit Akışı Borç oranı ise \%4'lere kadar gerilemiştir. Yine 2018 yılında elde edilen yüklü miktarda borçlanma karşılığı, Faiz Karşılama oranı 1,47’lere kadar gerilemiştir. Belediyenin 2018 yılında gerçekleştirdiği bu borçlanmanın varlık edinimi için gerçekleştirildiğini, başka bir ifade ile yatırım harcaması finansmanında kullanıldığını da, Varlıkların Nakit Getirisi ve yine Duran Varlık Nakit Akış oranlarının \%2'lere gerilemesinden anlaşılmaktadır. Genel itibariyle Beylikdüzü belediyesinin, 2018 yılında yabancı kaynak finansmanı ile yatırıma yöneldiği, 2017 ve 2019 yıllarında ise genel anlamda kısa vadeli borçlarının \%15-\%20'si aralığında; özkaynaklarının ise \%11-\%13’ü aralığında esas faaliyetinden nakit yaratabildiği söylenebilir.

\section{Sonuç}

Özellikle kar amacı gütmeyen belediye birimlerinde, kamu ihtiyaçlarının karşılanması, kamusal varlıkların daha etkin ve verimli bir şekilde kullanılması için, kardan daha önemli bir kavram olan nakit kavramı üzerine odaklanılması ve iyi analiz edilmesi gerekmektedir.

Literatür incelendiğinde; Türkiye'de özel sektöre yönelik nakit akış analizlerine yer verildiği görülmüş ancak, yerel yönetim birimlerinin nakit akış analizlerinin yapıldı̆̆ı bir araştırmaya rastlanılmamıştır. Bu yönüyle çalışma, Türkiye'de belediye birimlerinin nakit akış tablosu kullanımının belirlenmesi ve nakit akış analizlerinin uygulanması yönünde ilk çalışma olma özelliği taşımaktadır.

51 İl Belediyesi, 30 Büyükşehir Belediyesi ve 39 İlçe belediyesinin dahil edildiği araştırmada, toplam 5 yıllık dönemi kapsayan 445 adet faaliyet raporu analize tabi tutulmuştur. Toplamda 120 belediye birimine ait faaliyet raporlarının 
incelendiği araştırmada, faaliyet raporlarında nakit akış tablosuna yer veren, Beyoğlu, Kağıthane ve Sarıyer Belediyeleri olmak üzere 3 adet belediyeye rastlanılmıştır. Elde edilen bulgular doğrultusunda, "Büyükşsehir belediyeleri faaliyet raporlarında nakit akış tablosuna yer vermektedir", "Il belediyeleri faaliyet raporlarında nakit akıs tablosuna yer vermektedir" ve "Illçe belediyeleri faaliyet raporlarında nakit akış tablosuna yer vermektedir" ifadelerinin geçersiz olduğu, belediyelerin faaliyet raporlarında nakit akış tablosuna yer vermedikleri tespit edilmiştir. Buna göre belediye birimleri tarafından nakit akış tablosu etkin bir şekilde kullanılmamaktadır ve ilgililere sunulmamaktadır sonucuna ulaşılmıştır.

Çalı̧̧mada, belediye birimleri için önem arz eden nakit akış tablosunun düzenlenmesine yol gösterici bir uygulamaya da yer verilmiş olup; Beylikdüzü belediyesinde gerçekleştirilen uygulamada, belediyenin 2017-2018-2019 yıllarına ait nakit akış tabloları hazırlanmış ve özel sektörde kullanılan nakit akış analizlerine tabi tutulmuştur. Nakit akış analizlerinin belediyeler üzerinde uygulanmasına yönelik yapılan bu analiz sonucunda, Beylikdüzü belediyesinin nakit akışlarının sağlandığ 1 faaliyetler yöntemine göre, model 4 büyüyen belediye modelinde yer aldı̆̆ı; yapılan oran analizi sonucunda da 2018 yllında yatırım harcamalarına ağırlık veren bir belediye görüntüsünde olduğu tespit edilmiştir. Nakit akışlarının sağlandığı faaliyetler analizine tabi tutulan bir diğer belediye olan Beyoğlu belediyesinin ise; model 6 genç belediye modelinde yer aldığı sonucuna ulaşılmıştır.

Gerek standartlar içerisinde yer alan, gerek adına standart yazılmış olan, gerekse de kamu kesimine ait muhasebe yönetmeliklerinin tümü içerisinde temel mali tablolar arasında adından daima söz ettiren nakit akış tablosunun, belediyeler, yerel yönetimler ile kamu kurum ve kuruluşlarında hazırlanmasına ve analizine yönelik araştırmaların ve çalışmaların artması; kamu kaynaklarının etkin ve verimli kullanılması, kamusal ihtiyaçların karşılanmasının sürdürülebilirliği adına önem arz etmektedir. Türkiye'de belediyelerin nakit akış tablosu kullanımına yönelik yapılan bu çalışma ile birlikte, gerek ilgili kamu kurumları yöneticileri, gerekse de akademisyenler tarafından bundan sonraki çalışmalarda, kamu kesimine yönelik daha geniş kapsamlı nakit akış uygulama ve analiz çalışmaları yapılması ihtiyacı ortaya konmuştur.

Hakem Değerlendirmesi: Dış bağımsız.

Çıkar Çatışması: Yazarlar çıkar çatışması bildirmemiştir.

Finansal Destek: Yazarlar bu çalışma için finansal destek almadığını beyan etmiştir.

Peer-review: Externally peer-reviewed.

Conflict of Interest: The authors has no conflict of interest to declare.

Grant Support: The authors declared that this study has received no financial support.

\section{Kaynakça}

5018 Kamu Mali Yönetim ve Kontrol Kanunu. Resmi Gazete (Sayı:25326). Erişim adresi https://www.mevzuat.gov.tr/ MevzuatMetin/1.5.5018.pdf

Akdoğan, N. ve Tenker, N. (2010). Finansal tablolar ve mali analiz teknikleri. Ankara: Gazi Kitabevi.

Beaver, William H. (1966). Financial ratios as predictors of failure. Journal of Accounting Research, 4, Empirical Research in Accounting: Selected Studies, (4), 71-111.

Carslaw, C. A., \& Mills, J. R. (1991). Developing ratios for effective cash flow statement analysis. Journal of Accountancy, $172(5), 63-66$.

Casey, C., \& Bartczak, N. (1985). Using operating cash flow data to predict financial distress: some extensions. Journal of Accounting Research, 23(1), 384-401.

Çavuş, G. \& Başar, B. (2020). Finansal başarısızlık durumunun öngörülmesinde nakit akış bilgilerinin rolü. Muhasebe Bilim Dünyası Dergisi, Özel Sayl, 292-318.

Deakin, E. (1972). A discriminant analysis of predictors of business failure. Journal of Accounting Research, 10(1), $167-179$.

Dereköy, F. (2020). Borç ödeme gücünün ölçülmesinde geleneksel oranlar ile nakit akış oranlarının karşılaştırılması: İmalat sektörü örneği. Uluslararası Ekonomi, İşletme ve Politika Dergisi, 4(1), 151-168. 
Fridson, M., \& Alvarez, F. (2002). Financial statements analysis: A practitioner's guide. USA: John Wiley ve Sons.

Genel yönetim muhasebe yönetmeliği. Resmi Gazete (Sayı: 29214). Erişim adresi https://www.mevzuat.gov.tr/MevzuatMetin/3.5. 20147052.pdf

Giacomino, D. E., \& Mielke, D. E. (1993). Cash flows: Another approach to ratio analysis. Journal of Accountancy, $175(\mathrm{I}), 55-58$.

Gombola, M. J. ve Ketz, J. E. (1983). A note on cash flow and classification patterns of financial ratios. Accounting Review, 58(1), 105-114.

Gombola, M. J., Haskins, M. E, Ketz, J. E. \& Williams, D. D. (1987) Cash flow in bankruptcy prediction. Financial Management, 16(4), $55-65$.

Gup, B. E., Samson, W. D., Dugan, M. T., Kim, M. J. \& Jittrapanun, T. (1993). An analysis of patterns from the statement of cash flows. Financial Practice and Education, 3(2), 73-79.

Gücenme, Ü. \& Arsoy, A. P. (2006). Muhasebe standartlarındaki sınıflandırılmış nakit akım tablosu formatı ile finansal performansın ölçülmesi. Muhasebe ve Finansman Dergisi, (30), 66-74.

Güleç, Ö.F. \& Bektaş, T. (2019). Cash flow ratio analysis: The case of Turkey. Muhasebe ve Finansman Dergisi, Ağustos Özel Sayl, $247-262$

Jooste, L. (2006). Cash flow ratios as a yardstick for evaluating financial performance in african businesses. Managerial Finance, 32(7), 569-576.

Büyük ve orta boy işletmeler için finansal raporlama standardı. Erişim adresi www.kgk.gov.tr

Türkiye muhasebe ve finansal raporlama standartları. Erişim adresi www.kgk.gov.tr

Kargın, M. \& Aktaş, R. (2011). Türkiye muhasebe standartlarına göre raporlanmış nakit akış tablosu ve analizi. Muhasebe ve Finansman Dergisi, (52), 1-24.

Kepçe, N. (2017). Nakit akış tablosu alternatif bir yaklaşım. Eskişehir: Nisan Kitabevi Yayınları.

Kepçe. N. (2017). Can we evaluate economic features of companies by using cash flow information in a different way? Evidence From Turkish Manufacturing Industry. Bankacılık ve Finansal Araştırmalar Dergisi, 4(2), 62-69

Kirkham, R. (2012). Liquidity analysis using cash flow ratios and traditional ratios: The telecommunications sector in Australia. Journal of New Business Ideas ve Trends, 10(1), 1-13.

Largay III, J. A. \& Stickney, C. P. (1980). Cash flows, ratio analysis and the WT grant company bankruptcy. Financial Analysts Journal, 36(4), 51-54.

Mahalli idareler bütçe ve muhasebe yönetmeliği. Resmi Gazete (Say1: mük. 29724). Erişim adresi https://www.resmigazete.gov.tr/ eskiler/2016/05/20160527M1-1.htm

Merkezi yönetim muhasebe yönetmeliği. Resmi Gazete (Say1 :2 6392). Erişim adresi https://www.resmigazete.gov.tr/ eskiler/2006/12/20061230M3-1.htm

Mills, J. \& Yamamura, J. H. (1998). The power of cash flow ratios. Journal of Accountancy, 186(4), 53-61.

Mulford, C. W. \& Comiskey, E. E. (1996). Financial Warnings, John Wiley, New York. (aktaran Steyn-Bruwer, Wilma S., Hamman, W.D, 2005, 1-17.)

Orhan, S.M. \& Serçemeli, M. (2013). Tahakkuk esaslı devlet muhasebesinde bütçe hesapları ve muhasebeleştirilmesi. Atatürk Üniversitesi Sosyal Bilimler Enstitüsü Dergisi, 17(1), 321-334.

Örten, R., Kaval, H. \& Karapınar, H. (2015). Türkiye muhasebe finansal raporlama standartları uygulama ve yorumları TMS- TFRS. Ankara: İlksan Matbaası.

Özerhan, Y. \& Yanık, S. (2010). TMS/TFRS: Açıklamalı ve örnek uygulamalı Türkiye muhasebe standartları. Ankara: TÜRMOB Yayınları.

Pinson, L. (2007). Keeping the books: Basic recordkeeping and accounting for the successful small business, 7th ed. USA: Dearborn Trade Publishing. 
Porwal, H. K. \& Jain, S. (2013). Cash flow ratios to predict 1nvestment's soundness. Asia-Pacific Finance and Accounting Review, 1(4), $55-76$.

Rezaei, M. \& Jafari, S. M. (2015). Identifying the relationship between financial leverage and cash flows of the companies listed in Tehran stock exchange. Indian Journal of Science and Technology, 8(27), 1-13.

Rujoub, M. A., Cook, D. M. \& Hay, L. E. (1995). Using cash flow ratios to predict business failures. Journal of Managerial Issues, 7(1), $75-90$.

Sakarya, Ş. \& Akkuş, H. T. (2015). Finansal performansın ölçülmesinde geleneksel oranlar ile nakit akım oranlarının karşılaştırmalı analizi: Bist çimento şirketleri üzerine topsis yöntemi ile bir uygulama. Afyon Kocatepe Üniversitesi Íktisadi ve İdari Bilimler Fakültesi Dergisi, 17(1), 109-123.

Sarığlu, K. \& Demir, V. (2008). Seçilmiş türkiye finansal raporlama standartları-açıklamalar/uygulamalar. İstanbul: İSMMMO Yayınlar1.

Sayari, N. \& Mugan, F. C. S. (2013). Cash flow statement as an evidence for financial distress. Universal Journal of Accounting and Finance, 1(3), 95-102.

Steyn-Bruwer, Wilma S. \& Hamman, W.D., (2005). Cash flow patterns in listed South African industrial companies. Meditari Accountancy Research, 13(1), 1-17.

T.C. Çevre ve Şehircilik Bakanlığı. (2012). 6360 Sayılı on üç ilde büyükşehir belediyesi kurulması ile bazı kanun ve kanun hükmünde kararnamelerde değişiklik yapılmasına dair kanun (2012, 12 Kasım). Resmi Gazete (Sayı: 28489). Erişim adresi www.mevzuat.gov.tr > MevzuatMetin > 1.5.6360.doc, https://yerelyonetimler.csb.gov.tr

T.C. Hazine ve Maliye Bakanlığı. (2008). Devlet muhasebe standartlarl. Erişim adresi https://www.hmb.gov.tr/ devlet-muhasebesi-standartlari

Weygandt, J., Kimmel, P. \& Kieso, D. (2009). Accounting principles. USA: John Wiley ve Sons, Inc.

Yılmaz, H. (1999). İşletmelerin finansal yönetiminde nakit akış rasyo analizi. Dokuz Eylül Üniversitesi İktisadi ve İdari Bilimler Fakültesi Dergisi, 14(1), 185-198.

Yılmaz, M. K. \& İçten, O. (2018). Borsa İstanbul'da işlem gören gayrimenkul yatırım ortaklıklarının nakit akımı odaklı finansal performans analizi (2007-2016). Finans Politik ve Ekonomik Yorumlar, 55(635), 73-87.

Zeller, T. L. \& Stanko, B. B. (1994). Operating cash flow ratios measure a retail firm's ability to pay. Journal of Applied Business Research, 10(4), 51-59. 